\title{
The contribution of tephra constituents during biogenic silica determination: implications for soil and palaeoecological studies
}

\author{
W. Clymans ${ }^{1}$, L. Barão ${ }^{2}$, N. Van der Putten ${ }^{1}$, S. Wastegård ${ }^{3}$, G. Gísladóttir ${ }^{4}$, S. Björck ${ }^{1}$, B. Moine ${ }^{5}$, E. Struyf ${ }^{2}$, and \\ D. J. Conley ${ }^{1}$ \\ ${ }^{1}$ Department of Geology, Lund University, Sölvegatan 12, 22362 Lund, Sweden \\ ${ }^{2}$ Department of Biology, Ecosystem Management, University of Antwerp, Universiteitsplein 1, 2610 Wilrijk, Belgium \\ ${ }^{3}$ Department of Physical Geography, Stockholm University, 10691 Stockholm, Sweden \\ ${ }^{4}$ Institute of Life and Environmental Sciences, and the Nordic Volcanological Center, University of Iceland, Sturlugata 7, \\ 101 Reykjavík, Iceland \\ ${ }^{5}$ Université de Lyon, Magmas et Volcans (UBP-UJM-CNRS-IRD), 23 rue Dr. P. Michelon, 42023 Saint-Etienne, France \\ Correspondence to: W. Clymans (wim.clymans@geol.lu.se)
}

Received: 7 November 2014 - Published in Biogeosciences Discuss.: 25 February 2015

Revised: 21 May 2015 - Accepted: 23 May 2015 - Published: 22 June 2015

\begin{abstract}
Biogenic silica (BSi) is used as a proxy by soil scientists to identify biological effects on the Si cycle and by palaeoecologists to study environmental changes. Alkaline extractions are typically used to measure $\mathrm{BSi}$ in both terrestrial and aquatic environments. The dissolution properties of volcanic glass in tephra deposits and their nanocrystalline weathering products are hypothesized to overlap those of BSi; however, data to support this behaviour are lacking. The potential that Si-bearing fractions dissolve in alkaline media $\left(\mathrm{Si}_{\mathrm{Alk}}\right)$ that do not necessarily correspond to BSi brings the applicability of BSi as a proxy into question. Here, analysis of 15 samples reported as tephra-containing allows us to reject the hypothesis that tephra constituents produce an identical dissolution signal to that of BSi during alkaline extraction. We found that dissolution of volcanic glass shards is incomplete during alkaline dissolution. Simultaneous measurement of $\mathrm{Al}$ and $\mathrm{Si}$ used here during alkaline dissolution provides an important parameter to enable us to separate glass shard dissolution from dissolution of BSi and other Si-bearing fractions. The contribution from volcanic glass shards (between 0.2 and $4 \mathrm{wt} \% \mathrm{SiO}_{2}$ ), the main constituent of distal tephra, during alkaline dissolution can be substantial depending on the total $\mathrm{Si}_{\mathrm{Alk}}$. Hence, soils and lake sediments with low BSi concentrations are highly sensitive to the additional dissolution from tephra constituents and its
\end{abstract}

weathering products. We advise evaluation of the potential for volcanic or other non-biogenic contributions for all types of studies using BSi as an environmental proxy.

\section{Introduction}

Many plant and algae species take up dissolved silica (DSi) from the environment and produce biogenic silica (BSi), a hydrated, amorphous $\mathrm{SiO}_{2}$ polymorph that provides structural and physiological benefits (Guntzer et al., 2012). BSi is regularly estimated by soil scientists or palaeoecologists using various alkaline extraction techniques. These extraction techniques have supplanted other methods in general usage, including microfossil counts (Leinen et al., 1977), infrared spectroscopy (Meyer-Jacob et al., 2014) and X-ray diffraction. Each technique has specific benefits and limitations (Ohlendurf and Storm, 2008). The alkaline extraction techniques are applied to a range of environments and archives, including soils, peat deposits, lake and marine sediments, wetland and floodplain deposits, and suspended matter in rivers (Andresen et al., 2004; Clymans et al., 2011a, b; Cornelis et al., 2010; Fernández et al., 2013; Frings et al., 2014b; Verschuren et al., 2002). In terrestrial ecosystems vegetation may buffer DSi delivery to streams and rivers (Churchman 
and Lowe, 2012; Struyf and Conley, 2012). Hence, the magnitude of BSi accumulation in soils is a key component in the biological buffering capacity of the Si cycle in an ecosystem. Palaeoecologists use BSi as a proxy for diatom productivity, and apply this to infer changes in, for example, nutrient availability (Conley et al., 1993; Heathcote et al., 2014), hydrology (Andresen et al., 2004), atmospheric circulation (Harper et al., 1986; Johnson et al., 2011; Verschuren et al., 2002) and temperature (Adams and Finkelstein, 2010; Prokopenko et al., 2006).

The methods vary in detail, but all assume a difference in dissolution rate that forms the basis of the separation of $\mathrm{Si}$ from mineral silicates and amorphous biological fractions. Within the range of alkaline solutions used in the experiments a fraction of the material may release $\mathrm{Si}$ at a slow and apparently constant rate over the duration of the extraction (from here on referred to as a "linearly dissolving fraction"). This corresponds to dissolution of mineral silicates (Conley and Schelske, 2001; Koning et al., 2002). Some fractions may rapidly release some or all of their Si within the duration of the extraction (from here on "non-linearly dissolving fractions") and this non-linear fraction is conventionally interpreted as the BSi fraction (DeMaster, 1981).

Unfortunately, various non-BSi fractions also release $\mathrm{Si}$ either completely or partly in a non-linear manner in alkaline media, bringing the interpretation of the non-linear part as biological in origin into question (Cornelis et al., 2011a; Gehlen and van Raaphorst, 1993; Koning et al., 2002). Cornelis et al. (2011b) reviewed sources that may completely dissolve and find that in addition to biogenic remains (e.g. phytoliths, diatoms), inorganic forms such as Al-Si precipitates, volcanic glass shards, adsorbed $\mathrm{Si}$ on amorphous iron oxides, and nanocrystalline fractions such as allophanes and imogolite can comprise a substantial portion of the nonlinearly dissolving Si. Partial dissolution of clays can also rapidly release Si (Barão et al., 2015; Koning et al., 2002). We introduce a procedural term " $\mathrm{Si}_{\mathrm{Alk}}$ " (alkaline extracted $\mathrm{Si})$ to refer to the full range of Si-bearing phases that dissolve non-linearly under normal experimental conditions. It is becoming apparent that $\mathrm{Si}_{\mathrm{Alk}}$ does not necessarily correspond only to the BSi fraction, and thus caution is warranted due to its implications for interpretation of the putative $\mathrm{BSi}$ record in both soil and palaeoecological studies.

Several studies have suggested that glass shards and their weathering products (e.g. nanocrystalline minerals and secondary clays) could affect $\mathrm{Si}_{\mathrm{Alk}}$ measurements, as their dissolution characteristics in alkaline solutions can overlap with the biogenic fraction (Barão et al., 2015; Hashimoto and Jackson, 1960; Sauer et al., 2006). Discrete volcanic ash deposits, composed of shards, minerals, pumice and rock fragments, also known as tephra, are common in sedimentary archives. Indeed, they form the basis of tephrochronology (e.g. Lowe, 2011), a powerful technique for establishing age equivalence between sites. If dissolving glass (or mineral grain) in a tephra releases $\mathrm{Si}$ in a similar way to $\mathrm{BSi}$ during dissolution in alkaline solutions, it has the potential to make interpretation of $\mathrm{Si}_{\text {Alk }}$ difficult, since a change will not uniquely represent a change in environmental conditions but also perhaps periods of volcanic activity. Additionally, because of their often rapid dissolution, glass, pumice, and other constituents in tephra can potentially induce elevated DSi concentrations in lakes, causing shifts in phytoplankton communities (Lotter et al., 1995; Hickman and Reasoner, 1994). Such a shift in the sedimentary record may be incorrectly ascribed to a change in environmental conditions providing a secondary indirect pathway to biased interpretations.

Here, we investigate volcanic glass shards and their weathering products as a confounding factor during $\mathrm{Si}_{\mathrm{Alk}}$ determination. We tested (1) dissolution characteristics of glass in tephra deposits, (2) whether tephra-derived constituents contribute to $\mathrm{Si}_{\mathrm{Alk}}$ measurements during alkaline extraction, and (3) how such contributions affect the $\mathrm{Si}_{\text {Alk }}$ measurements in soils, sediments and peats. We find that glass shards do not produce an identical dissolution signal to that of BSi during alkaline extractions. However, the contribution of glass shards to BSi can be substantial when low BSi concentrations are encountered in environmental archives with important repercussions for soil and palaeoecological studies.

\section{Materials and methods}

\subsection{Tephra samples}

Fifteen samples reported as tephra-containing and covering a representative range of chemical composition (basaltic to rhyolitic), eruption dates (from AD 2010 back to $48 \mathrm{ka}$ ), geographical provenance (northern and southern latitudes) and environments (fresh deposits, soils, lakes and peat archives) have been retrieved from archived samples (Table 1; Fig. 1). We used tephra collections from tephra deposits described previously in soil and palaeoecological studies representing a gradient in weathering state.

\subsection{Sample treatment}

All samples were split into two parts to develop two distinct sample sets: untreated and treated. Untreated samples were immediately subjected to alkaline extraction (Sect. 2.3). The goal of treating samples is to isolate relatively pure biogenicand volcanic-glass-derived fractions, which will allow us to evaluate the robustness of the inferences made from the dissolution of the untreated samples. Samples were subjected to standard pre-treatment and heavy-liquid separation, described below, with additional magnetic separation or sieving steps where necessary (Mackie et al., 2002; Morley et al., 2004; Turney, 1998). 
Table 1. The tephra name, provenance, sample environment, eruption date and composition of the specific tephra deposits analysed.

\begin{tabular}{|c|c|c|c|c|c|}
\hline Tephra & Origin & Profile & $\mathrm{Age}^{1}$ & Composition & Reference \\
\hline Hekla1991 & Iceland & Fresh deposit & $1991 \mathrm{AD}$ & Basaltic andesite & Gudmundsson et al. (1992) \\
\hline EFJ2010_SJV & Iceland & Fresh deposit & $2010 \mathrm{AD}$ & Trachyandesite & Unpublished data ${ }^{3}$ \\
\hline EFJ2010_1504 & Iceland & Fresh deposit & $2010 \mathrm{AD}$ & Trachyandesite & Gislason et al. (2011a, b) \\
\hline Fogo A & Azores, Portugal & Buried soil & $5000 \mathrm{cal} \mathrm{BP}^{5}$ & Trachyte & Johansson et al. $(2015)^{4}$ \\
\hline PAS-2T39 & Argentina & Lake & 48742 cal BP & Rhyolite & Wastegård et al. (2013) \\
\hline TC09_48a & Kerguelen Islands & Buried soil & $1000 \mathrm{cal} \mathrm{BP}^{5}$ & Trachyte & Unpublished data ${ }^{5}$ \\
\hline Pompeii & Italy & Buried soil & $79 \mathrm{AD}$ & Tephriphonolite & Unpublished data $^{6}$ \\
\hline Vedde Ash & Iceland & Fresh deposit & $12100 \mathrm{cal} \mathrm{BP}$ & Mixed basalt and rhyolite & Norddahl and Hafliðason $(1992)^{2}$ \\
\hline Reykjanes1226 & Iceland & Soil & $1226 \mathrm{AD}$ & Basalt & Gísladóttir G. et al. (2010) \\
\hline Cav-A & Azores, Portugal & Peat bog & $1000 \mathrm{cal} \mathrm{BP}$ & Tephrite & Björck et al. (2006) \\
\hline Saksunarvatn & Faroe Islands & Lake & $10300 \mathrm{cal} \mathrm{BP}$ & Basalt & Lind and Wastegård (2011) + Tephrabase \\
\hline Tuhua & New Zealand & Lake & $7165 \mathrm{cal} \mathrm{BP}$ & Peralkaline rhyolite & Heyng et al. (2012) \\
\hline Armor1000 & Kerguelen Islands & Peat bog & $1000 \mathrm{cal} \mathrm{BP}^{5}$ & Trachyte & Unpublished data ${ }^{7}$ \\
\hline Katla1500 & Iceland & Soil & $1500 \mathrm{AD}$ & Basalt & Hafliðason et al. (1992) \\
\hline Reclus $\mathrm{R}_{1}$ & Argentina & Lake & $15000 \mathrm{cal} \mathrm{BP}$ & Rhyolite & Unkel et al. (2008) \\
\hline
\end{tabular}

${ }^{1}$ Reported ages expressed as calendar years (AD), calibrated ${ }^{14} \mathrm{C}$ ages (cal BP; BP being $1950 \mathrm{AD}$ by convention) and approximations based on unpublished radiocarbon dates. ${ }^{2}$ Referred to as the Skógar tephra. ${ }^{3}$ Surface grab sample collected shortly after 2010 eruption at the south side in Seljavellir $\left(63^{\circ} 34^{\prime} \mathrm{N} ; 19^{\circ} 37^{\prime} \mathrm{W}\right)$ and stored dried; the EPMA data used are for a typical EFJ ash as reported in Gislason et al. (2011b). ${ }^{4}$ Surface grab sample collected from the airfall deposit $\left(37^{\circ} 43^{\prime} 10.6 \mathrm{~N}, 25^{\circ} 30^{\prime} 0.96 \mathrm{~W}\right)$, stored dried. ${ }^{5}$ Sampled along a natural cut through the fluvial, volcano-sedimentary and peat deposits, at southeast of the Rallier du Baty Peninsula ( $\left.49^{\circ} 41^{\prime} 42^{\prime \prime} \mathrm{S}, 68^{\circ} 57^{\prime} 55^{\prime \prime} \mathrm{E}\right)$; dry pumices were extracted from the ignimbrite deposit and stored dried. ${ }^{6}$ Sample taken during archaeological investigation of Pompeii, quarter VI.30, room $2\left(40^{\circ} 45^{\prime} \mathrm{N}, 14^{\circ} 29^{\prime} \mathrm{E}\right)$, stored dried. ${ }^{7}$ The Armor peat sequence $\left(49^{\circ} 27.872 \mathrm{~S}, 69^{\circ} 43.484 \mathrm{E}\right)$ was sampled by drilling in CALYPSO PVC tubes $(\phi=11.5 \mathrm{~cm})$, and stored cold $\left(4^{\circ} \mathrm{C}\right)$ before being freeze-dried.

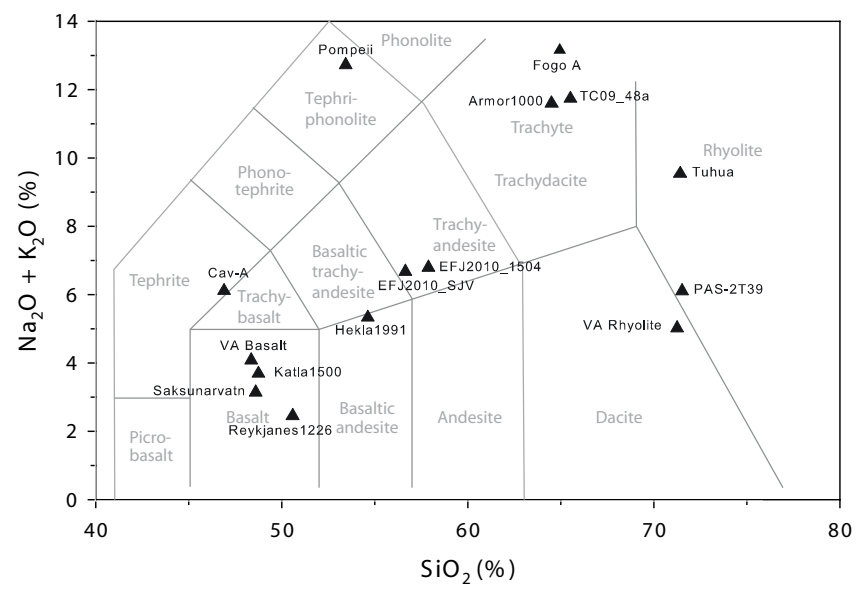

Figure 1. Composition of glass shards in our tephra samples presented on a total alkali silica diagram $\left(\mathrm{SiO}_{2}\right.$ vs. $\left.\mathrm{Na}_{2} \mathrm{O}+k_{2} \mathrm{O}\right)$, a standard classification used for pyroclastic volcanic rocks based on non-genetic features. Geochemical boundaries are according to Le Bas et al. (1986). Data are normalized averages of EPMA. No data are available for the Reclus $\mathrm{R}_{1}$ sample.

\subsubsection{Pre-treatment}

A $0.5-1 \mathrm{~g}$ subsample was weighed into a $15 \mathrm{~mL}$ centrifuge tube to which $30 \%$ hydrogen peroxide $\left(\mathrm{H}_{2} \mathrm{O}_{2}\right)$ was repeatedly added to remove organic matter at $80^{\circ} \mathrm{C}$ until reaction cessation. One millilitre of $10 \% \mathrm{HCl}$ solution was added to disaggregate the material and dissolve any soluble inorganics (e.g. carbonates) and left until the reaction ceased. After each treatment step, the sample was washed three times in deionized water (Milli-Q).

\subsubsection{Heavy-liquid separation}

Heavy liquid separation is used to obtain concentrated siliceous organism samples (i.e. diatoms and sponges) (Morley et al., 2004) and concentrated glass shard samples (e.g. Turney, 1998). The biogenic part is concentrated by centrifuging in sodium polytungstate (SPT) with a relative density of $2.3 \mathrm{~g} \mathrm{~cm}^{-3}$. Prior to each centrifuge step, samples were thoroughly mixed, and if necessary placed in an ultrasonic bath to disaggregate the material. The floating material $\left(<2.3 \mathrm{~g} \mathrm{~cm}^{-3}\right)$ was dried $\left(70^{\circ} \mathrm{C}\right)$ and assessed with SEM for purity, i.e. biogenic material, or possible contamination from pumice and other non-biogenic light fractions. The residue $\left(>2.3 \mathrm{~g} \mathrm{~cm}^{-3}\right)$ was centrifuged in SPT at a relative density of $2.5 \mathrm{~g} \mathrm{~cm}^{-3}$. Both floating material (between 2.3 and $\left.2.5 \mathrm{~g} \mathrm{~cm}^{-3}\right)$ and residue $\left(>2.6 \mathrm{~g} \mathrm{~cm}^{-3}\right)$ were washed with Milli-Q. The latter should contain heavy minerals, and only a limited amount of glass shards, which should instead be concentrated within the 2.3 to $2.5 \mathrm{~g} \mathrm{~cm}^{-3}$ bracket. All residues were microscopically checked for their purity.

The separation only rarely resulted in high-purity end products. Additional ad hoc sample specific treatments were conducted to improve the separation. In the case of a high concentration of low-density shards (e.g. pumice) within the biogenic sample $\left(<2.3 \mathrm{~g} \mathrm{~cm}^{-3}\right)$, a wet-sieving step was used to separate the biogenic siliceous bodies from shards. Size distributions for each fraction were determined using light microscopy (Nikon SMZ1500, ×16) and the NIS-Elements software for size measurements. The selected mesh size corresponded with the point of minimum overlap. In the case of basaltic tephra shards (i.e. $>2.7 \mathrm{~g} \mathrm{~cm}^{-3}$ ), magnetic sepa- 
ration of the $>2.6 \mathrm{~g} \mathrm{~cm}^{-3}$ (Mackie et al., 2002) was applied to concentrate pure basaltic shards.

\subsection{Alkaline extraction techniques}

Two different alkaline extractions were used to determine the $\mathrm{Si}_{\text {Alk }}$ content and dissolution characteristics of the untreated and the isolated tephra and biogenic silica fractions of the treated samples: the sequential $0.1 \mathrm{M} \mathrm{Na}_{2} \mathrm{CO}_{3}$ and the continuous $0.5 \mathrm{M} \mathrm{NaOH}$ method.

\subsubsection{Sequential wet-alkaline extraction method: $0.1 \mathrm{M}$ $\mathrm{Na}_{2} \mathrm{CO}_{3}$}

The $\mathrm{Na}_{2} \mathrm{CO}_{3}$ extraction is a weak-base method developed by DeMaster (1981), who described that while alumino-silicates release Si linearly over time, most BSi dissolves completely within the first $2 \mathrm{~h}$ of the digestion. In our analysis (Conley and Schelske, 2001), approximately $30 \mathrm{mg}$ of dried sample $(<2 \mathrm{~mm})$ was mixed in $40 \mathrm{~mL}$ of $0.1 \mathrm{M} \mathrm{Na}_{2} \mathrm{CO}_{3}$ solution and digested for $5 \mathrm{~h}$ at $85^{\circ} \mathrm{C}$. A $0.5 \mathrm{~mL}$ aliquot was removed after 3,4 and $5 \mathrm{~h}$ and neutralized with $4.5 \mathrm{~mL}$ of $0.021 \mathrm{M}$ $\mathrm{HCl}$, before DSi determination via the automated molybdateblue method (Grasshoff et al., 1983) using a Smartchem 200 (AMS Systea) discrete analyser. The $\mathrm{Si}_{\text {Alk }}$ was calculated by determining the intercept of the regression between total extracted $\mathrm{Si}$ and extraction time. Extrapolating the Si release to the intercept is assumed to correct for mineral dissolution of $\mathrm{Si}$. To evaluate its suitability to correct for mineral dissolution, the typical subsampling scheme was prolonged to $24 \mathrm{~h}$ and additional $0.5 \mathrm{~mL}$ subsamples were taken at 9,10 and $11 \mathrm{~h}$ and again at 20,22 and $24 \mathrm{~h}$, and diluted in $9.5 \mathrm{~mL}$ of $0.010 \mathrm{M} \mathrm{HCl}$ instead of $4.5 \mathrm{~mL}$ to obtain optimal dilution.

\subsubsection{Continuous extraction method: $0.5 \mathrm{M} \mathrm{NaOH}$}

We applied a stronger $\mathrm{NaOH}(0.5 \mathrm{M})$ digestion protocol (Barão et al., 2014; Koning et al., 2002) with continuous monitoring of the extracted $\mathrm{Si}$ and aluminium $(\mathrm{Al})$ concentration through time. Briefly, between 20 and $100 \mathrm{mg}$ of a sample was mixed with $180 \mathrm{~mL}$ of $0.5 \mathrm{M} \mathrm{NaOH}(\mathrm{pH}=13.7)$ in a stainless steel vessel. The vessel was incubated in a water bath at a constant temperature of $85^{\circ} \mathrm{C}$ and continuously stirred with a rotor to obtain a homogeneous mixture. The vessel was sealed to prevent evaporation. The extraction fluid was fed into a Skalar continuous flow analyser at $0.42 \mathrm{~mL} \mathrm{~min}^{-1}$. Si and Al concentrations were determined simultaneously using the spectrophotometric molybdate-blue method for Si (Grasshoff et al., 1983) and lumogallion fluorescence for $\mathrm{Al}$ (Hydes and Liss, 1976) for 30-40 min.
A simultaneous fit of dissolved $\mathrm{Si}$ and $\mathrm{Al}$ curves was performed using Eq. (1).

$$
\begin{aligned}
& \mathrm{Si}_{\mathrm{t}}=\left(\sum_{x=1}^{\mathrm{n}} \mathrm{Si}_{\mathrm{Alk}, x} \times\left(1-\mathrm{e}^{-\mathrm{k}_{x} \times \mathrm{t}}\right)\right)+b \times t \\
& \mathrm{Al}_{\mathrm{t}}=\left(\sum_{\mathrm{x}=1}^{\mathrm{n}} \frac{\mathrm{Si}_{\mathrm{Alk}, x}}{\mathrm{Si}: \mathrm{Al}_{x}} \times\left(1-\mathrm{e}^{-k_{\mathrm{x}} \times \mathrm{t}}\right)\right)+\frac{b \times t}{\mathrm{Si}: \mathrm{Al}_{\text {min }}},
\end{aligned}
$$

where $\mathrm{Si}_{t}$ and $\mathrm{Al}_{t}$ is the pool of extracted silica and aluminum at time $t\left(\mu \mathrm{mol} \mathrm{L}{ }^{-1}\right), \mathrm{Si}_{\mathrm{Alk}, x}$ is the total pool of $\mathrm{Si}_{\text {Alk }}$ $\left(\mu \mathrm{mol} \mathrm{L}{ }^{-1}\right)$ of fraction $x, k$ is a parameter that reflects the non-linear reactivity of the sample $\left(\min ^{-1}\right), b$ reflects the linear reactivity, and $\mathrm{Si}: \mathrm{Al}_{x}$ and $\mathrm{Si}: \mathrm{Al}_{\min }$ represent their respective $\mathrm{Si}$ : Al ratios. The dissolution curves of $\mathrm{Si}$ and $\mathrm{Al}$ were used to identify fractions based on their $\mathrm{Si}: \mathrm{Al}$ ratios. This principle was first applied by Koning et al. (2002) in marine sediment samples, where almost all alkaline extracted $\mathrm{Si}$ has a biogenic source, overprinted by a low $\mathrm{Si}: \mathrm{Al}_{x}$ component from clay mineral dissolution. They showed that some fractions that would be considered as biogenic using linear phase extrapolation (i.e. the sequential extraction, above) were actually clay contamination, based on the low $\mathrm{Si}: \mathrm{Al}_{x}$ ratios (between 1 and 4 ) in these fractions. We hypothesize that glass from tephra will resemble such behaviour because of their relatively high $\mathrm{Al}$ content. The $k$ parameter reflects how fast a Si-bearing fraction reaches complete dissolution in an alkaline media, and depends on bonding strengths and specific reactive surface areas. Here, relative differences of $k$ values between modelled fractions are used to classify high and low reactive fractions in alkaline media, where nanocrystalline and absorbed Si fractions are suggested to be more rapidly released as compared to biogenic Si fractions (Barão et al., 2015).

The number of fractions $(x)$ in the first-order model was determined by consecutively allowing an extra fraction to obtain an optimal model fit (i.e. reducing the RMSE using the Solver function within Microsoft Excel).

\section{Results}

\subsection{Sequential wet-alkaline extraction method $-0.1 \mathrm{M}$ $\mathrm{Na}_{2} \mathrm{CO}_{3}$}

Alkaline silica $\left(\mathrm{Si}_{\mathrm{Alk}}\right)$ extracted from a total of 14 tephracontaining samples (EFJ2010_1504 not included) based on the 3-5 $\mathrm{h}$ mineral dissolution slope (wt $\% \mathrm{SiO}_{2} \mathrm{~h}^{-1}$ ) varies between 0.3 and $16.7 \mathrm{wt} \% \mathrm{SiO}_{2}$ with an average of $3.01 \pm 3.91 \mathrm{wt} \% \mathrm{SiO}_{2}$. Mineral dissolution slope ranges between 0.03 and $0.65 \mathrm{wt} \% \mathrm{SiO}_{2} \mathrm{~h}^{-1}$ with an average of $0.35 \pm 0.21 \mathrm{wt} \% \mathrm{SiO}_{2} \mathrm{~h}^{-1}$. This high standard deviation suggests variability within samples, but is heavily influenced by two outliers (Reclus $\mathrm{R}_{1}$ and Tuhua tephra); median $\mathrm{Si}_{\text {Alk }}$ and mineral dissolution slope are $1.56 \mathrm{wt} \% \mathrm{SiO}_{2}$ and 0.28 wt $\% \mathrm{SiO}_{2} \mathrm{~h}^{-1}$, respectively. 
The median $\mathrm{Si}_{\text {Alk }}$ using the $20-24 \mathrm{~h}$ mineral dissolution slope was $3.63 \mathrm{wt} \% \mathrm{SiO}_{2}$ with a median slope of $0.12 \mathrm{wt} \%$ $\mathrm{SiO}_{2} \mathrm{~h}^{-1}$. A paired $t$ test (signed rank) showed that both (corrected) $\mathrm{Si}_{\text {Alk }}$ concentrations and mineral dissolution slope differed significantly between the 3-5 and the 20-24 h sampling intervals.

There is a large variability in the shape of the curves in extracted Si through time (Fig. 2). Some samples exhibit a continuously gently decreasing slope with time (Fig. 2a), while others show initial rapid dissolution followed by a steep linear increase (Fig. 2b), whereas others increase rapidly but are followed by no increase or only a minimal increase in Si extracted with time (Fig. 2c). Numerically, we define this gradient through comparing the $\mathrm{Si}_{\text {Alk }}$ after $3-5 \mathrm{~h}$ with those obtained after 20-24 h (Table 2): we observe high (3.0-7.1), medium (1.5-2.5) and low (1-1.8) ratios. Ideally, constant mineral dissolution with no additional amorphous $\mathrm{Si}$ extracted after $3 \mathrm{~h}$ would correspond to a ratio of 1 .

\subsection{Continuous alkaline extraction method: $0.5 \mathrm{M}$ $\mathrm{NaOH}$}

\subsubsection{Curve decomposition}

Results of curve fitting of the continuous monitored $\mathrm{Si}$ and $\mathrm{Al}$ data during the extractions are presented in Table 3 and Figs. 2 and 3 . $\mathrm{Si}_{\mathrm{Alk}}$ concentrations vary between 0.27 and $23.4 \mathrm{wt} \% \mathrm{SiO}_{2}$ with an average of $4.54 \pm 6.08 \mathrm{wt} \% \mathrm{SiO}_{2}$ and a median of $2.31 \mathrm{wt} \% \mathrm{SiO}_{2}$. On average, but not always, these concentrations are significantly higher than those measured during the $\mathrm{Na}_{2} \mathrm{CO}_{3} 3-5 \mathrm{~h}$ extraction (Sect. 3.1; $p=0.0016$ ), but do not differ significantly with the $\mathrm{Na}_{2} \mathrm{CO}_{3}$ 20-24 h extraction ( $p=0.1540$; non-parametric $t$ test). However, relative differences between the $\mathrm{NaOH}$ and $\mathrm{Na}_{2} \mathrm{CO}_{3} 3-$ $5 \mathrm{~h}$ extraction can be up to a factor of $2-5$, and values tend to be lower (up to 10 times) than those measured during the $\mathrm{Na}_{2} \mathrm{CO}_{3} 20-24$ h extraction.

The shape of the dissolution curves suggests the presence of three distinct dissolution patterns similar to using the $\mathrm{Na}_{2} \mathrm{CO}_{3}$ methodology. A first set of curves show a gently decreasing slope with time, and limited contribution of Al (Fig. 2d - group 1). The second set of curves shows a rapid increase at the onset for both $\mathrm{Si}$ and $\mathrm{Al}$, and afterwards evolves towards a more linear increase (Fig. 2e - group 2). The final set is characterized by a rapid increase at the onset with varying contributions of $\mathrm{Al}$, but mostly an order of magnitude lower than extracted Si concentrations with a near zero or high mineral dissolution slope (Fig. 2f - group 3).

Optimal fits of the model to predict the dissolution curve included between one and three different $\mathrm{Si}_{\text {Alk }}$ fractions each with a specific $k$ parameter and $\mathrm{Si}$ to $\mathrm{Al}$ ratio (Table 3). We used the number of non-linear fractions (first order - see Eq. 1) and their $\mathrm{Si}: \mathrm{Al}_{x}$ to group the samples (see discussion, Fig. 2d-f, and Table 3). One group of samples exhibited one non-linear fraction that was released slowly with a $k$ between 0.05 and $0.5 \mathrm{~min}^{-1}$. The linear dissolution is responsible for the majority of the increase in $\mathrm{Si}$ and $\mathrm{Al}$ concentrations through time. $\mathrm{Si}$ : $\mathrm{Al}_{x}$ ratios for both fractions are approximately equal and range between 3 and 5 .

A second group has two fractions that dissolve non-linearly. The non-linear fractions evolve rapid $\left(k>0.7 \mathrm{~min}^{-1}\right)$ and slow $\left(k<0.5 \mathrm{~min}^{-1}\right)$, respectively, towards complete dissolution. $\mathrm{The} \mathrm{Si}: \mathrm{Al}_{x}$ ratio of the slow fraction falls between 1 and 2.5. The rapid reaction releases typically more $\mathrm{Al}$, leading to low $\mathrm{Si}: \mathrm{Al}$ ratios $(<1)$. The $\mathrm{Si}: \mathrm{Al}_{\min }$ ratio of the linear fraction ranges between 1 and 3.5. Finally, two fractions that dissolve non-linearly typify a third set of samples: a rapid $\left(k>0.7 \mathrm{~min}^{-1}\right)$ fraction with $\mathrm{Si}: \mathrm{Al}_{x}$ mostly below 1 and a slow fraction $\left(k<0.5 \mathrm{~min}^{-1}\right)$ with $\mathrm{Si}: \mathrm{Al}_{x}$ above 8 . One exception (Reclus $\mathrm{R}_{1}$ ) has three fractions but no mineral fraction and differs by having two slow fractions instead of one.

\subsubsection{Validation of curve decomposition procedure}

Dissolution curves using $0.5 \mathrm{M} \mathrm{NaOH}$ for all concentrated shard samples (rhyolitic: between 2.3 and $2.5 \mathrm{~g} \mathrm{~cm}^{-3}$; basaltic $>2.5 \mathrm{~g} \mathrm{~cm}^{-3}$ ) were best approximated with a single non-linear fraction and a linear (i.e. mineral) fraction, indicating successful physical separation of shards (see Table 4). Mineral dissolution contributions were typically large in total $\mathrm{Si}$ and $\mathrm{Al}$ release, being the main source after on average 5 min of dissolution for $\mathrm{Al}$ release. The initial $\mathrm{Si}$ and $\mathrm{Al}$ release appears to be faster than before the cleaning and separation treatment. This is reflected in higher $\mathrm{Si}: \mathrm{Al}_{x}$ ratios and $k$ values. One exception - the Reclus $\mathrm{R}_{1}$ sample - did not contain a retrievable amount of shards.

The BSi-rich samples $\left(<2.3 \mathrm{~g} \mathrm{~cm}^{-3}\right)$ were fitted with a single non-linear fraction in absence of a linear fraction. The only exception is the Tuhua tephra, where two non-linear fractions with varying dissolution rate were fitted, defined as a rapid (0.47) and slow $(0.05) k$. All $\mathrm{Si}: \mathrm{Al}_{x}$ were higher than 100. The total extracted Si content averaged $72 \pm 11 \mathrm{wt} \%$ $\mathrm{SiO}_{2}$.

\section{Discussion}

Earlier studies have hypothesized that volcanic glass shards substantially contribute to measured $\mathrm{Si}_{\text {Alk }}$ (Cornelis et al., 2011b; Lyle and Lyle, 2002; Sauer et al., 2006). In the following, we discuss the specific dissolution characteristics of glass shards, during alkaline extraction and implications for soil and palaeoecological studies. We formulate guidelines for the use of alkaline extraction techniques to determine BSi in soils and sediments prone to volcanic glass inputs.

\subsection{Incomplete dissolution during digestion}

In theory, $\mathrm{Si}_{\mathrm{Alk}}$ should be insensitive to the choice of aliquot times during $\mathrm{Na}_{2} \mathrm{CO}_{3}$ extraction, if the dissolution of miner- 

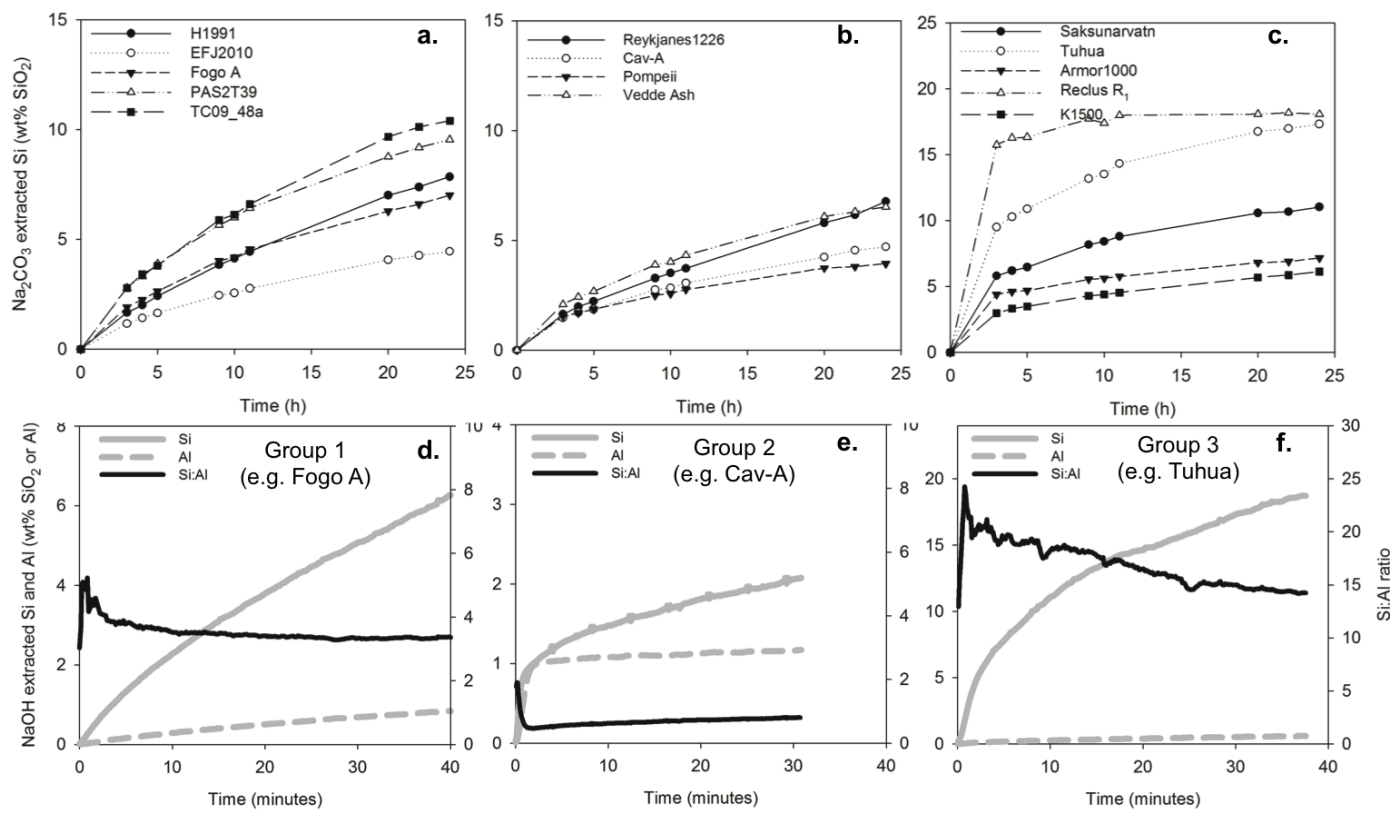

Figure 2. Dissolution curves of untreated tephra deposits grouped by characteristic features during the semi continuous extraction with $\mathrm{Na}_{2} \mathrm{CO}_{3}(\mathbf{a}-\mathbf{c})$ for $\mathrm{Si}$ and continuous extraction $\mathrm{NaOH}(\mathbf{d}-\mathbf{f})$ for $\mathrm{Si}, \mathrm{Al}$ and $\mathrm{Si}$ : Al ratio. Note: groups are the same between methods but the time unit on the $x$ axis differs between $(\mathbf{a}-\mathbf{c})$ and $(\mathbf{d}-\mathbf{f})$. For $\mathrm{NaOH}$ only one representative curve per group is presented. Group 1 contains Hekla1991, both EFJ2010 samples, Fogo A, PAS-2T39 and TC09_48a; group 2 contains Reykjanes1226, Cav-A, Pompeii and Vedde Ash; group 3 contains Saksunarvatn, Tuhua, Armor1000, Katla1500 and Reclus $\mathrm{R}_{1}$.

Table 2. Comparison of $\mathrm{Si}_{\mathrm{Alk}}$ (wt $\% \mathrm{SiO}_{2} \pm \mathrm{SD} ; n=5$ ) of 14 selected tephra deposits for two commonly applied methods: $0.1 \mathrm{M} \mathrm{Na}_{2} \mathrm{CO}_{3}$ based on 3-5 and 20-24 h mineral dissolution slopes and 0.5 M NaOH. Note: sample EFJ2010_1504 is not included.

\begin{tabular}{lrrrr}
\hline Tephra name & $3-5 \mathrm{~h} \mathrm{Na}_{2} \mathrm{CO}_{3}$ & $20-24 \mathrm{~h} \mathrm{Na}_{2} \mathrm{CO}_{3}$ & $\mathrm{NaOH}$ & $\mathrm{Si}_{\text {Alk, 20-24h }} / \mathrm{Si}_{\text {Alk, 3-5 }}$ \\
\hline Hekla1991 & $0.49 \pm 0.27$ & 2.75 & 0.27 & 5.61 \\
EFJ2010_SJV & $0.30 \pm 0.15$ & $2.14 \pm 0.25$ & 0.30 & 7.13 \\
Fogo A & $0.91 \pm 0.29$ & $2.66 \pm 0.23$ & 1.68 & 2.92 \\
PAS-2T39 & $1.35 \pm 0.31$ & 4.82 & 2.32 & 3.57 \\
TC09_48a & $1.13 \pm 0.27$ & 6.00 & 4.34 & 5.31 \\
Pompeii & $1.08 \pm 0.05$ & $2.73 \pm 0.46$ & 0.90 & 2.53 \\
Reykjanes1226 & $1.31 \pm 0.40$ & 0.87 & 2.30 & 0.66 \\
Vedde Ash & $1.54 \pm 0.41$ & 3.86 & 1.86 & 2.51 \\
Saksunarvatn & $5.82 \pm 1.13$ & 8.23 & 5.57 & 1.41 \\
Cav-A & $1.13 \pm 0.19$ & 1.91 & 1.60 & 1.69 \\
Tuhua & $7.73 \pm 0.59$ & 14.00 & 10.53 & 1.81 \\
Armor1000 & $4.09 \pm 0.37$ & $4.96 \pm 1.09$ & 3.51 & 1.21 \\
Katla1500 & $2.18 \pm 0.48$ & $3.39 \pm 1.04$ & 4.89 & 1.56 \\
Reclus $\mathrm{R}_{1}$ & $16.68 \pm 1.32$ & 18.10 & 23.47 & \\
& & & & \\
\hline
\end{tabular}

als does not violate the two key assumptions of the original protocol outlined by DeMaster (1981): (i) complete dissolution of all $\mathrm{Si}_{\mathrm{Alk}}$ fractions within $3 \mathrm{~h}$ and (ii) the mineral fraction should exhibit linear behaviour during the course of the dissolution experiment. The linear behaviour is assumed to be caused by minimal changes in reactive surface area of crystalline minerals during dissolution in a weak base, e.g. $0.1 \mathrm{M} \mathrm{Na}_{2} \mathrm{CO}_{3}$.
Higher $\mathrm{Si}_{\text {Alk }}$ concentrations (Table 2) and lower mineral dissolution slope values after 20-24 h for our samples suggest a prolonged non-linear behaviour. We interpret this as evidence for incomplete dissolution of alkali-extractable fractions within the first $3 \mathrm{~h}$ of extraction. Complete dissolution of glass takes considerably longer than $3 \mathrm{~h}$, causing $\mathrm{Si}_{\text {Alk }}$ to be underestimated when sub-sampling only over the $3-5 \mathrm{~h}$ time period. In addition, a decrease in reactivity dur- 
Table 3. Modelled dissolution parameters after alkaline $(\mathrm{NaOH})$ extraction of untreated samples. For each fraction $\left(\mathrm{Si}_{\mathrm{Alk}, x} ; \mathrm{wt} \% \mathrm{SiO} 2\right)$ the $\mathrm{Si}: \mathrm{Al}_{x}$ ratios, rate of non-linear dissolution/release $k_{x}\left(\mathrm{~min}^{-1}\right)$ for fraction $x$, and the slope $b\left(\mathrm{wt} \% \mathrm{SiO}_{2} \mathrm{~min}^{-1}\right)$ of the mineral dissolution with a $\mathrm{Si}: \mathrm{Al}_{\min }$ ratio are given for all samples. Additional column representing the $\mathrm{Si}$ and $\mathrm{Al}$ ratio of unweathered shards based on available EPMA data $\left(\mathrm{Si}: \mathrm{Al}_{\text {solid }}\right)$.

\begin{tabular}{|c|c|c|c|c|c|c|c|c|c|c|c|c|c|}
\hline \multirow[t]{2}{*}{ Sample } & \multicolumn{3}{|c|}{ Fraction 1} & \multicolumn{3}{|c|}{ Fraction 2} & \multicolumn{3}{|c|}{ Fraction 3} & \multicolumn{2}{|c|}{ Mineral } & \multirow{2}{*}{$\begin{array}{r}\text { Total } \\
\mathrm{Si}_{\text {Alk,tot }}\end{array}$} & \multirow{2}{*}{$\begin{array}{c}\mathrm{EPMA}^{*} \\
\mathrm{Si}: \mathrm{Al}_{\text {solid }}\end{array}$} \\
\hline & $\mathrm{Si}_{\mathrm{Alk}, 1}$ & $k_{1}$ & $\mathrm{Si}: \mathrm{Al}_{1}$ & $\mathrm{Si}_{\mathrm{Alk}, 2}$ & $k_{2}$ & $\mathrm{Si}: \mathrm{Al}_{2}$ & $\mathrm{Si}_{\text {Alk }, 3}$ & $k_{3}$ & $\mathrm{Si}: \mathrm{Al}_{3}$ & $b$ & $\mathrm{Si}: \mathrm{Al}_{\min }$ & & \\
\hline Hekla1991 & 0.27 & 0.45 & 4.03 & - & - & - & - & - & - & 0.032 & 3.25 & 0.27 & 3.35 \\
\hline EFJ2010_SJV & 0.30 & 0.15 & 3.41 & - & - & - & - & - & - & 0.027 & 4.08 & 0.30 & 3.41 \\
\hline EFJ2010_1504 & 1.24 & 0.16 & 3.53 & - & - & - & - & - & - & 0.116 & 3.59 & 1.24 & 3.44 \\
\hline Fogo A & 1.68 & 0.11 & 3.98 & - & - & - & - & - & - & 0.108 & 3.12 & 1.68 & 3.44 \\
\hline PAS 2 T39 & 2.32 & 0.11 & 4.92 & - & - & - & - & - & - & 0.130 & 4.17 & 2.32 & 4.89 \\
\hline TC09_48a & 3.58 & 0.05 & 3.59 & 0.76 & 1.01 & 0.95 & - & - & - & 0.188 & 3.57 & 4.34 & 3.86 \\
\hline Pompeii & 0.45 & 0.23 & 1.19 & 0.45 & 1.77 & 2.17 & - & - & - & 0.041 & 1.58 & 0.90 & 2.35 \\
\hline Vedde Ash & 0.90 & 0.11 & 1.73 & 0.96 & 0.94 & 4.40 & - & - & - & 0.057 & 3.54 & 1.86 & 3.94 \\
\hline Reykjanes 1226 & 0.68 & 0.05 & 2.15 & 1.62 & 1.65 & 1.03 & - & - & - & 0.038 & 1.19 & 2.30 & 3.84 \\
\hline Saksunarvatn & 2.15 & 0.21 & 2.31 & 3.42 & 1.89 & 3.55 & - & - & - & 0.057 & 3.71 & 5.57 & 3.31 \\
\hline Cav-A & 0.58 & 0.05 & 8.00 & 1.02 & 1.05 & 0.46 & - & - & - & 0.017 & 2.13 & 1.60 & 2.97 \\
\hline Tuhua & 8.01 & 0.14 & 26.26 & 2.52 & 0.74 & 22.40 & - & - & - & 0.201 & 8.71 & 10.53 & 7.21 \\
\hline Armor1000 & 2.89 & 0.19 & 26.83 & 0.61 & 1.12 & 0.37 & - & - & - & 0.079 & 4.31 & 3.51 & 3.58 \\
\hline Katla1500 & 2.01 & 0.16 & 13.42 & 2.88 & 0.46 & 0.91 & - & - & - & 0.038 & 2.36 & 4.89 & 3.57 \\
\hline Reclus $\mathrm{R}_{1}$ & 10.31 & 0.19 & 9.03 & 13.12 & 0.18 & 18.05 & 0.04 & 0.31 & 0.60 & 0.000 & 0.01 & 23.47 & N/A \\
\hline
\end{tabular}

* Electron probe microanalysis (EPMA) data are based on available data (overview Table 1; Fig. 1).

ing the $24 \mathrm{~h}$ extraction violates the second assumption. Our samples must contain another fraction that violates the second assumption and only reaches a state of apparent linear dissolution after the $5 \mathrm{~h}$ sampling.

We observe a gradient in the severity (high, medium and low degree) of incomplete dissolution expressed as the deviation from an ideal $\mathrm{Si}_{\text {Alk }}(22-24 / 3-5 \mathrm{~h})$ ratio of 1 . Samples were grouped according to their extent of deviation from the ideal. Most samples are not newly formed pure volcanic deposits but instead a complex set of samples from lakes, soils and peat bogs (Table 1). We suggest that the differences in the extent of dissolution and in their dissolution curves represent variations in composition and abundance of different $\mathrm{Si}_{\text {Alk }}$ sources. Unfortunately, the $\mathrm{Na}_{2} \mathrm{CO}_{3}$ method cannot define the origin of the different $\mathrm{Si}_{\mathrm{Alk}}$ fractions. This makes quantification of the contribution of volcanic material to $\mathrm{BSi}$ impossible.

\subsection{Towards separation of the different fractions}

The use of $\mathrm{Si}: \mathrm{Al}$ ratios with the continuous $\mathrm{NaOH}$ extraction methodology can improve the interpretation of dissolution and uncertainty of the Si source (Barão et al., 2014). NaOH should also be more efficient in dissolving all amorphous and nanocrystalline material present (Müller and Schneider, 1993; Gehlen and van Raaphorst, 1993). We combine dissolution parameters in $\mathrm{NaOH}$ with microscopy to attribute specific dissolving or releasing fractions to our three defined groups (see Sect. 3.2.1 and Fig. 3).

\subsubsection{A shard signature}

Group 1 represents relatively pure tephra samples (Fig. 2a, d) where dissolution of glass shards dominates. Our data suggest that glass shards release the majority of $\mathrm{Si}$ and $\mathrm{Al}$ at a rapid and a constant rate during the time period (ca. $30 \mathrm{~min}$ ) we monitor dissolution in $\mathrm{NaOH}$. In contrast to $\mathrm{Na}_{2} \mathrm{CO}_{3}$, the stronger $\mathrm{NaOH}$ seems to obtain apparent linear dissolution within the course of the experiment, after an initial non-linear release. This initial decrease in reactivity followed by a substantial constant $\mathrm{Si}$ and $\mathrm{Al}$ release corroborates previous observations describing the stoichiometric dissolution of glass shards (Oelkers and Gislason, 2001; Stephens and Hering, 2004). Si : Al ratios of the non-linear $\mathrm{Si}_{\mathrm{Alk}}$ and linear fraction coincide with $\mathrm{Si}$ : Al ratios from unweathered glass shards ( $\left.\mathrm{Si}: \mathrm{Al}_{\text {solid }}\right) . \mathrm{Si}: \mathrm{Al}$ ratios of the pure tephra samples (presumably mainly glass) are plotted along the $1: 1$ line, demonstrating stoichiometric behaviour (Fig. 4a).

Oelkers and Gislasson (2001) delivered a theoretical framework for volcanic glass shard dissolution at acidic and alkaline conditions that adequately describes our observed dissolution patterns in both $\mathrm{Na}_{2} \mathrm{CO}_{3}$ and $\mathrm{NaOH}$ solutions. Initially, proton exchange reactions will lead to the removal of univalent and divalent cations from the shard surfaces, followed by a partial removal of $\mathrm{Al}$ from the framework through the same process. Finally, Si liberation is possible through the weakened state of $\mathrm{Si}$ as it is present in $\mathrm{Si}$ tetrahedrals, i.e. only partially attached to the framework by only one or two bridging oxygen atoms primarily located at the edges and tips of the shard. As smoothening of the shards progresses, and depending on the abundance of hydrated sites, the weakened state of $\mathrm{Si}$ at the edges can lead to faster release of $\mathrm{Si}$ at the onset, which decreases as the edges be- 


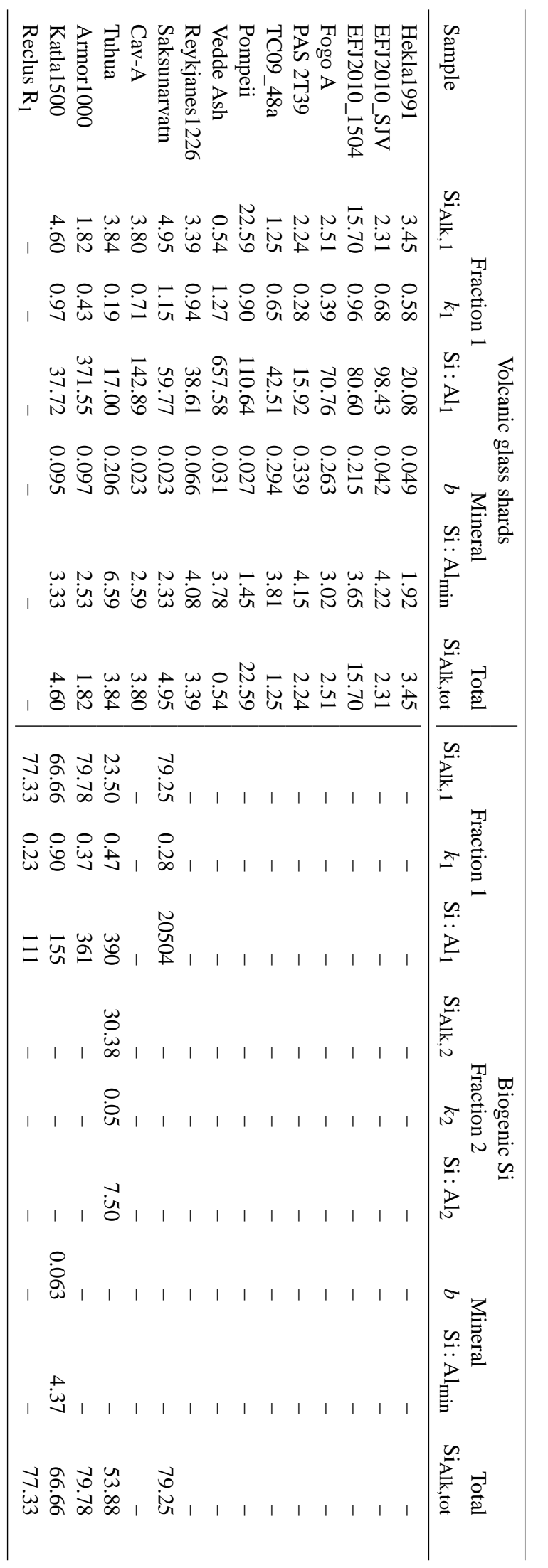

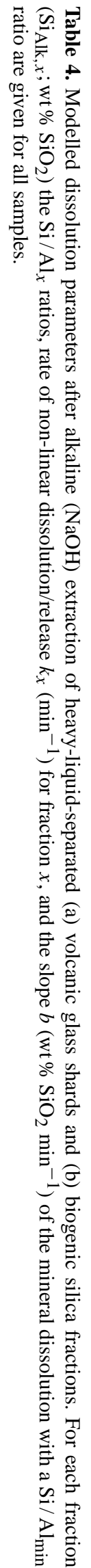




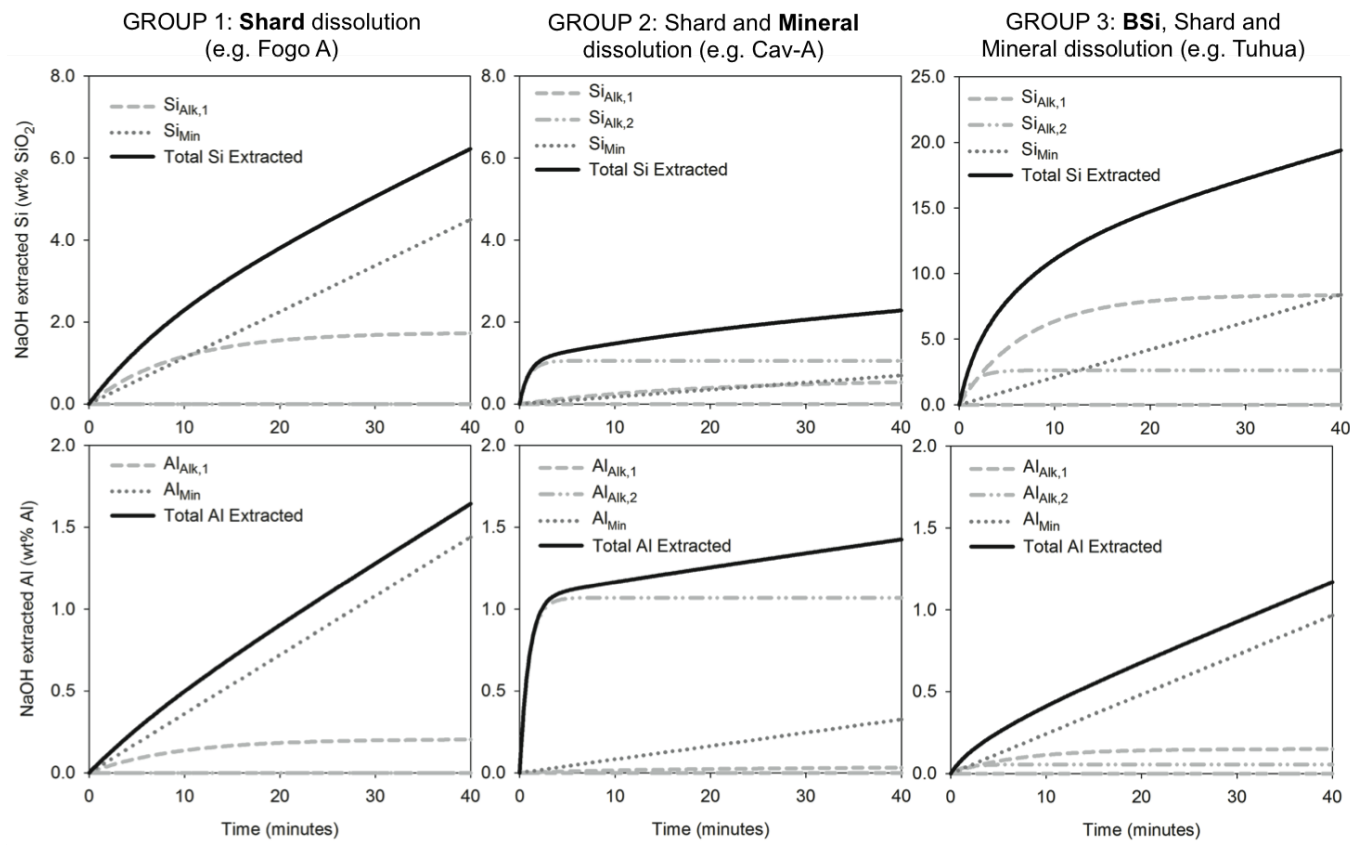

Figure 3. Separation in non-linear $\left(\mathrm{Si}_{\mathrm{Alk}}\right.$ and $\left.\mathrm{Al}_{\mathrm{Alk}}\right)$ and linear $\left(\mathrm{Si}_{\mathrm{Min}}\right.$ and $\left.\mathrm{Al}_{\mathrm{Min}}\right)$ fractions based modelling the continuous dissolution curves of Si and Al using Eq. (1). Grouped by dominant fraction (in bold): shards, minerals (i.e. nanocrystalline and clay minerals) or biogenic Si. Group 1 contains Hekla1991, both EFJ2010 samples, Fogo A PAS-2T39 and TC09_48a; group 2 contains Reykjanes1226, Cav-A, Pompeii and Vedde Ash; group 3 contains Saksunarvatn, Tuhua, Amor1000, Katla1500 and Reclus $\mathrm{R}_{1}$.
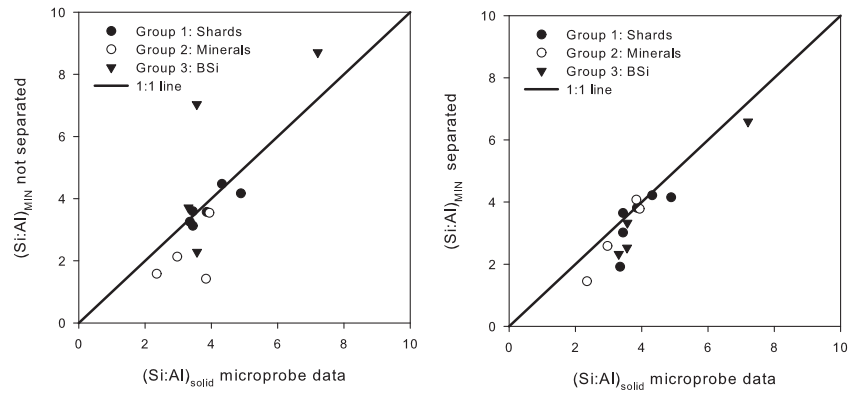

Figure 4. Comparison of $\mathrm{Si}: \mathrm{Al}_{\text {solid }}$ (from EPMA) and $\mathrm{Si}: \mathrm{Al}_{\min }$ during alkaline dissolution (Table 3 ). Grouped by dominant fraction: shards (solid circles), minerals (open circles, i.e. nanocrystalline and clay minerals) or biogenic Si (triangles). No data are available for Reclus $\mathrm{R}_{1}$ sample.

come rounded. The rounding of edges is responsible for the observed $\mathrm{Si}_{\text {Alk }}$ content when glass shards are dissolved. Afterwards, glass shards will continue to release $\mathrm{Si}$ and $\mathrm{Al}$ at a steady stoichiometric rate (see also Hodder et al., 1990). Hence, the dissolution pattern reflects the continuous but incomplete dissolution of glass shards. This process makes the dissolution of glass shards distinct from the dissolution of other non-biogenic (e.g. nanocrystalline minerals) or biogenic fractions and adsorbed $\mathrm{Si}$ and $\mathrm{Al}$ release. These processes occur rapidly at the onset of $\mathrm{NaOH}$ extraction but do not lead to a fast constant release after unspecified time (Barão et al., 2014; Hashimoto and Jackson, 1960).

Based on the pure samples of tephra (i.e. glass-rich), we suggest that shards have a distinct dissolution signature discernable using continuous monitoring during a $0.5 \mathrm{M} \mathrm{NaOH}$ extraction. The three defining characteristics are as follows: (1) the mineral dissolution slope is extremely high $(0.028$ $0.120 \mathrm{wt} \% \mathrm{SiO}_{2} \min ^{-1}$ ) with (2) a $\mathrm{Si}: \mathrm{Al}$ ratio in the extracted aqueous phase between 3 and 5 equal to that of unweathered shards, confirming stoichiometric dissolution and its volcanic origin, and (3) a slow non-linear fraction with $\left(\mathrm{Si}: \mathrm{Al}_{\mathrm{aq}} / \mathrm{Si}: \mathrm{Al}_{\text {solid }}\right)= \pm 1$ indicates an initial stoichiometric dissolution until edges are rounded (Table 3; Fig. 4). Reanalysis with the $\mathrm{NaOH}$ method of isolated glass shards is consistent with a constant and stoichiometric dissolution of shards with time (Fig. 5b). Unfortunately, chemical pre-treatment with $\mathrm{HCl}$ and $\mathrm{H}_{2} \mathrm{O}_{2}$ has affected the dissolution characteristics of the shards creating an initial more rapid release of $\mathrm{Si}$ and $\mathrm{Al}$.

We propose that acidic conditions during the cleaning procedure lead to partial dissolution of the volcanic glass shards as shown by Wolff-Boenisch et al. (2004) in acidic and farfrom-equilibrium conditions for a range of shards (low and high $\mathrm{SiO}_{2}$ content). The process at acid conditions can be equally described as for alkaline solutions through the twophase process of deprotonation of $\mathrm{Al}$ followed by liberation of Si (Oelkers and Gislason, 2001). However, Al is preferentially released due to the formation of a silica gel layer at 


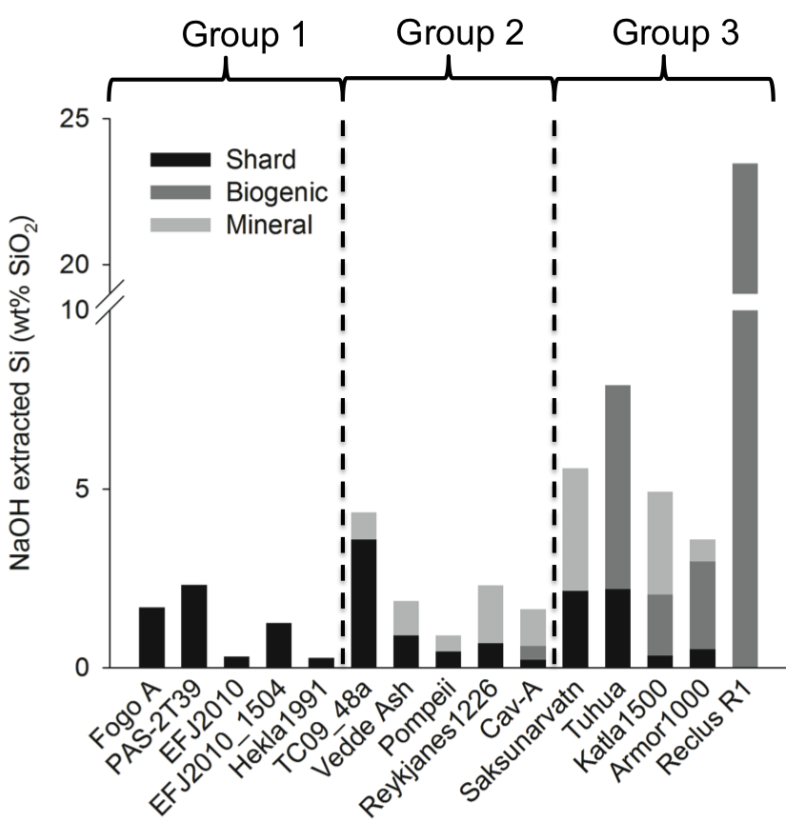

Figure 5. Separation of biogenic vs. non-biogenic (i.e. mineral or shard) fractions during alkaline extractions for all selected tephra deposits. Note: TC09_48a was reclassified to group 2 as it has a non-biogenic $\mathrm{Si}_{\mathrm{Alk}}$ source.

$\mathrm{pH}<9$ with a thickness depending on the exposure time to acids (Pollard et al., 2003). Of course, addition to an alkaline environment led to a rapid dissolution of any enriched silica gel coating. This provides an explanation for the high $\mathrm{Si}: \mathrm{Al}_{x}$ ratios and rapid $\mathrm{Si}$ release rates after pre-treatment (Table 4). We advise against chemical pre-treatment when analysing for $\mathrm{BSi}$, because it causes the extraction of nonbiogenic fractions.

\subsubsection{Discerning a shard signature from non-biogenic $\mathbf{S i}_{\text {Alk }}$}

In groups 2 and 3 (Fig. 2), multiple non-linear fractions were observed when modelling dissolution curves. We attribute the contribution of shards to the $\mathrm{Si}_{\text {Alk }}$ fraction that evolves slowest to constant release (i.e. lowest $k$ ), while a low $\mathrm{Si}: \mathrm{Al}_{x}$ ratio suggests a non-biogenic source for the more rapid second $\mathrm{Si}_{\text {Alk }}$ fraction.

Groups 2 and 3 are samples from lake, soil and peat records. Here, shards are mixed with a variety of materials during deposition including organic carbon, minerals and siliceous organisms. The tephra samples with the highest contribution of the secondary $\mathrm{Si}_{\text {Alk }}$ fraction (e.g. Katla, Reykjanes, Saksunarvatn and the basaltic part of the Vedde Ash) have a lower stability according to Pollard's theoretical stability modelling (2003). Likewise, the Parker index value for the Tuhua tephra indicates a higher propensity for rapid weathering (Lowe, 1988). We suggest that enhanced weathering in these environments leads to the formation of secondary mineral and nanocrystalline fractions (Hodder et al., 1990). This would create an additional non-biogenic, alkaline extractable source. Such weathering products are typically enriched in $\mathrm{Al}$ with structural $\mathrm{Si}: \mathrm{Al}_{x}$ ratios between 1 and 3 for clay minerals (Dixon and Weed, 1989) and below 1 for nanocrystalline structures (Levard et al., 2012). In fact, they dissolve or release $\mathrm{Si}$ and $\mathrm{Al}$ more rapidly, and sometimes incongruently, at the beginning of a $\mathrm{NaOH}$ extraction (Hashimoto and Jackson, 1960; Koning et al., 2002). This explains why we observe a large range in $\mathrm{Si}: \mathrm{Al}_{x}$ ratios (0.54) initially during the extraction. We suggest that it either represents the non-linear part of clay dissolution $\left(\mathrm{Si}: \mathrm{Al}_{x}\right.$ ratio: 1-4) or complete dissolution of nanocrystalline minerals ( $\mathrm{Si}: \mathrm{Al}_{x}$ ratio: $\left.0.5-1\right)$.

Clay minerals will dissolve at a constant rate after an initial rapid release (Koning et al., 2002) similar to primary glass shards. Consequently, the linear part of the dissolution will reflect stoichiometric dissolution of glass shards ( $\mathrm{Si}: \mathrm{Al}_{\min }$ ratio: $\left.3-5\right)$ and clay minerals $\left(\mathrm{Si}: \mathrm{Al}_{\min }\right.$ ratio: $1-$ 3). Samples with increased abundance of clay contribution will have lowered $\mathrm{Si}: \mathrm{Al}_{\min }$ ratios compared to unweathered shards (Fig. 4a).

\subsubsection{Discerning a shard signature from biogenic $\mathrm{Si}_{\mathrm{Alk}}$}

In group 3, higher $\mathrm{Si}: \mathrm{Al}_{x}$ ratios $>5$ for the slower fraction suggest the presence of an additional biogenic $\mathrm{Si}_{\mathrm{Alk}}$ fraction. Biogenic fractions including diatoms, sponge spicules and phytoliths were identified in these samples microscopically. $\mathrm{BSi}$ measurements of the separated biogenic fraction using the continuous $\mathrm{NaOH}$ methodology had a single non-linear $\mathrm{Si}_{\text {Alk }}$ fraction, except Tuhua, with on average $72 \mathrm{wt} \% \mathrm{SiO}_{2}$. This fraction contains negligible amounts of $\mathrm{Al}$, and mineral dissolution is absent, confirming the biogenic nature of the separated material. The combined presence of diatoms and sponge spicules in the Tuhua samples explains the observation of two distinct BSi fractions (based on reactivity), as alkaline dissolution rates are known to vary between different siliceous organisms (Conley and Schelske, 2001).

Hence, it seems that the rounding of glass shards overlaps with the dissolution of biogenic material, with similar reactivity but higher $\mathrm{Si}: \mathrm{Al}_{x}$ ratios. The distinct pattern of pure shards can be used to make a minimum estimate of its contribution to the slower-reacting fraction. Identification of glass shards' dissolution behaviour is essential to evaluate the methods ability to estimate the biogenic $\mathrm{Si}_{\mathrm{Alk}}$ content and evaluate the relative contribution of shard dissolution to $\mathrm{Si}_{\text {Alk }}$. The separation is based on the near-to-one ratio between $\mathrm{Si}: \mathrm{Al}_{x}$ with the $\mathrm{Si}: \mathrm{Al}_{\text {solid }}$ (Fig. 4).

Assumption 1: $\mathrm{Si}: \mathrm{Al}$ corresponding to the slow fraction $\left(\mathrm{Si}_{\mathrm{Alk}, 1}\right)$ equals the $\mathrm{Si}: \mathrm{Al}$ of shards, or

$$
\left(\frac{\mathrm{Si}}{\mathrm{Al}}\right)_{1} \approx\left(\frac{\mathrm{Si}}{\mathrm{Al}}\right)_{\text {solid }} .
$$


Assumption 2: all $\mathrm{Al}$ originates from shards for the slow fraction, i.e. no $\mathrm{Al}$ release from the biogenic fraction. This leads to an overestimation of $\mathrm{Al}$ as small amounts $(<0.05 \mathrm{wt} \%)$ of $\mathrm{Al}$ are found in phytoliths and diatoms (Kameník et al., 2013; Van Cappellen et al., 2002).

$\mathrm{Al}_{1}=\mathrm{Al}_{\mathrm{Bsi}}+\mathrm{Al}_{\text {solid }}$ with $\mathrm{Al}_{\mathrm{BSi}}=0$.

Therefore,

$\mathrm{Al}_{1}=\mathrm{Al}_{\text {solid }}$

The Si coming from shards can then be calculated by substitution:

$\mathrm{Si}_{\text {solid }}=\left(\frac{\mathrm{Si}}{\mathrm{Al}}\right)_{\text {solid }} \cdot \mathrm{Al}_{1}$.

We know that

$\mathrm{Si}_{1}=\mathrm{Si}_{\mathrm{BSi}}+\mathrm{Si}_{\text {solid }}$

This delivers

$\mathrm{Si}_{\mathrm{Bsi}}=\mathrm{Si}_{1}-\mathrm{Si}_{\text {solid }}$

The results of this separation exercise combined with the observed difference in other fractions are provided in Fig. 5. A significant contribution of shards to $\mathrm{Si}_{\mathrm{Alk}}$ is observed for all samples except Reclus $\mathrm{R}_{1}$. Although we have no definitive explanation as to why our Reclus $\mathrm{R}_{1}$ sample did not contain observable amounts of shards, our results support the physical observation of no retrievable shard fraction by heavyliquid separation. If anything, it supports the appropriateness of the chemical analysis to detect the occurrence of shards.

Initial dissolution of shard edges varies between 0.1 and $8 \mathrm{wt} \% \mathrm{SiO}_{2}$ with a median contribution of $1.8 \mathrm{wt} \% \mathrm{SiO}_{2}$. The variation in contribution depends on how fragmented and weathered (i.e. partially dissolved) the glass shards are. There will be a decrease in its contribution if edges have been smoothed during natural dissolution processes. It shows that dissolution of glass shards can contribute substantially to the determination of BSi when BSi concentrations are low. Likewise, the non-biogenic Si sources (defined as "minerals" here) contribute between 0.2 and $5 \mathrm{wt} \% \mathrm{SiO}_{2}$ with a median contribution equal to $0.89 \mathrm{wt} \% \mathrm{SiO}_{2}$. The combined effect potentially exceeds the biogenic fraction (e.g. K1500), while for others it contributes to less than $10 \%$ of the total extracted Si pool (e.g. Armor1000 and Reclus $\mathrm{R}_{1}$ ).

\subsection{The tephra factor in soil and palaeoecological studies}

\subsubsection{Implications for soil scientists}

The global median $\mathrm{Si}_{\text {Alk }}$ in the top $1 \mathrm{~m}$ of the soil column using alkaline extraction techniques ranges between 0.79 and 1.12 wt $\% \mathrm{SiO}_{2}$ (e.g. Melzer et al., 2012; Saccone et al.,
2007; Sommer et al., 2013). The magnitude overlaps with $\mathrm{Si}_{\text {Alk }}$ content attributed to tephra, the initial rapid dissolution of clay minerals and/or complete dissolution of nanocrystalline fractions in our experiments (Fig. 5). A similar magnitude of Si release between soil samples and our untreated tephra samples during alkaline extraction implies that the combined dissolution of glass shards, and their weathering products, if present, can disguise the environmental signal of the BSi proxy for a limited amount of settings.

Glass shards are an important direct source of methodological bias in tephra-based soils, including Andosols (ISSSISRIC-FAO, 1998). Andosols have a limited spatial extent, covering about $1-2 \%$ of the land surface. Likewise, volcanic bedrock formed at the surface covers $6.6 \%$ of the land surface (Hartmann and Moosdorf, 2012) and is known to contain limited amounts of glass shards, which are a potential source of $\mathrm{Si}_{\text {Alk }}$ in soils. Further, glass shards can be an important component of soils developed in aeolian deposits in the Great Plains, USA (Reyerson, 2012). The inheritance of glass shards in some types of aeolian material might partly explain high $\mathrm{Si}_{\text {Alk }}$ in aeolian deposits measured by other studies (e.g. 4 wt \% $\mathrm{SiO}_{2}$; Saccone et al., 2007).

Better knowledge of the mineralogical composition of our samples could improve classification of the non-biogenic fractions. Weathering products of glass shards are proposed to be the largest contributor to the $\mathrm{Si}_{\mathrm{Alk}}$ fraction. $\mathrm{A} \mathrm{Si}: \mathrm{Al}_{x}$ ratio between 0.39 and 1.02 (five out of eight samples) for this fraction suggests its source to be nanocrystalline fractions. These fractions are typically described as allophanes and imogolites with a $\mathrm{Si}: \mathrm{Al}_{x}$ ratio between 0.5 and 1 (Levard et al., 2012), and dissolve completely within the first $5 \mathrm{~min}$ of alkaline extraction (Hashimoto and Jackson, 1960; Kamatani and Oku, 2000). Various studies have shown that these nanocrystalline minerals also develop in soils without a volcanic origin (Gustafsson et al., 1999; Parfitt, 2009). For example, in podzols, supersaturation of $\mathrm{Al}$ species at ambient dissolved Si concentration leads to the formation of allophanes and imogolites. Nanocrystalline structures are stable at ambient $\mathrm{pH}$ conditions above 5 (Parfitt, 2009). Extraction of $\mathrm{Si}_{\text {Alk }}$ will include them in the biological pools (Clymans et al., 2014) and lead to an overestimation of BSi in both volcanic and non-volcanic soils at ambient $\mathrm{pH}$ conditions.

We recommend caution when interpreting $\mathrm{Si}_{\mathrm{Alk}}$ measurements from Andosols, or soils developed on volcanic bedrock, at sites where inheritance of volcanic material through aeolian or water deposition is likely. The $\mathrm{NaOH}$ method (after Koning et al., 2002) has proven its ability to pinpoint problematic samples and separate the biogenic from non-biogenic fractions. The method provides an excellent opportunity to improve the determination of BSi pools in soil profiles. 


\subsubsection{Implications for palaeoecological studies}

Biogenic silica, estimated as $\mathrm{Si}_{\mathrm{Alk}}$, has proven to be a valuable tool in palaeoecological studies as an indicator of environmental changes (e.g. changes in productivity, climate, precipitation and nutrient supply). In lacustrine sediment cores, BSi content can range from the detection limit $(0.01 \mathrm{wt} \%)$ to $>70 \mathrm{wt} \% \mathrm{SiO}_{2}$ (Frings et al., 2014a). The downcore variations in BSi through time vary from as little as $2 \mathrm{wt} \% \mathrm{SiO}_{2}$ (Adams and Finkelstein, 2010; Ampel et al., 2008) to a high of 10-40 wt \% $\mathrm{SiO}_{2}$ (Johnson et al., 2011; Prokopenko et al., 2006; Van der Putten et al., 2015) and depends on several interacting factors such as mineral matter or organic matter accumulation, diatom productivity and preservation/dissolution processes. Hence, these processes control the relative effect that tephra constituents $\left(<3 \mathrm{wt} \% \mathrm{SiO}_{2}\right.$, Fig. 5) have on $\mathrm{Si}_{\text {Alk }}$ determination. In palaeorecords, where there is a potential contribution of tephra combined with low $\mathrm{Si}_{\text {Alk }}$ concentrations or small downcore variations in $\mathrm{Si}_{\text {Alk }}$, $\mathrm{Si}_{\text {Alk }}$ should be used with caution as an environmental proxy.

The accuracy of the alkaline extraction methods as a proxy for BSi concentrations in sediment will depend on the origin of the mineral matter. Koning et al. (2002) suggested that good results with the $\mathrm{NaOH}$ method can be obtained for $\mathrm{BSi}$ / clay ratios of about 0.005 , whereas for $\mathrm{Na}_{2} \mathrm{CO}_{3}$ good values can be obtained from a ratio of 0.02 . We show that for tephra samples it is a bit more complicated as rounding of the glass shards edges and dissolution of its weathering products (i.e. nanocrystalline minerals and secondary minerals) also contribute to the apparent BSi fraction. Obviously, the spatial and therefore temporal extent of potential contribution is restricted to core sections representing episodes of (1) direct tephra deposition, and subsequent in situ reworking, or (2) indirect contribution through mobilization of tephra and its weathering products in a tephra-covered landscape.

Our study highlights a direct effect of tephra on quantification of BSi. Additionally, tephra deposition in lakes and peatlands can alter the diatom community composition and diatom abundance (Harper et al., 1986; Hickman and Reasoner, 1994; Lotter et al., 1995), though not always (Telford et al., 2004). Tephra input can induce a change in water chemistry, causing altered diatom growth and/or preservation (for a review see Harper et al., 1986). In such a case, the increase in BSi accumulation can be indirectly attributed to tephra deposition rather than to environmental changes. The methods used in our study cannot distinguish between tephrainduced diatom blooms and those resulting from short- or long-term environmental change. Nevertheless, zones in a sediment record potentially prone to a tephra-induced bloom can be highlighted based on reconnaissance of glass shard contributions. This research topic warrants further investigation, and requires detailed analysis of high-resolution records known to be prone to volcanic inputs.

\subsubsection{Implications for pre-treatment steps of EPMA during tephrochronological studies}

Tephrochronology requires geochemical fingerprinting of tephra through electron probe microanalysis (EPMA) (Lowe, 2011). EPMA on tephra requires that they be unaltered by natural or laboratory processes. Unfortunately, tephra shards are sensitive to dissolution at high and low $\mathrm{pH}$, conditions that are both naturally occurring and frequently applied during pre-treatment (e.g. Blockley et al., 2005; Dugmore et al., 1992). Therefore, corrosive chemical pre-treatment is increasingly avoided in tephrochronological studies and has been replaced by heavy-liquid floatation protocols (Blockley et al., 2005; Turney, 1998). The use of $\mathrm{NaOH}$ (typically $0.3 \mathrm{M}$ in tephra preparation studies) for cleaning tephra samples of biogenic Si (Davies et al., 2003; Rose et al., 1996; Wulf et al., 2013) should be used with great caution. Our study demonstrates that alkaline treatments lead to severe dissolution of shards, and can negatively affect the reconnaissance of shards for EPMA analysis. Our data show that dissolution of the shards was equivalent to $4 \mathrm{wt} \% \mathrm{SiO}_{2}$ in the first $40 \mathrm{~min}$ (Fig. 2a) and that a complete dissolution is attained in less than a day. The severity of the dissolution effect depends on the duration of extraction, the temperature at which extraction is performed and the molarity of the solution used (Müller and Schneider, 1993). Good criteria for $\mathrm{NaOH}$ cleaning are that extraction times should (1) allow complete BSi dissolution and (2) limit shard dissolution to a maximum of $10 \mathrm{wt} \% \mathrm{SiO}_{2}$ so that a sufficient number of undamaged shards remain for EPMA analysis. Finally, the Si and $\mathrm{Al}$ data suggest stoichiometric dissolution of shards, implying that their geochemical composition will remain unaltered. We cannot be conclusive as modelled $\mathrm{Si}$ : $\mathrm{Al}$ ratios are too imprecise and the release of other dominant constituents (e.g. Na, K) was not monitored. EPMA on samples before and after alkaline treatment (preferentially $\mathrm{NaOH}$ ) could resolve this issue.

\section{Conclusion}

Various wet chemical alkaline extraction techniques commonly used to measure $\mathrm{Si}_{\mathrm{Alk}}$ content have been criticized regarding their usefulness outside marine sciences. Problems are attributed to dissolution of non-biogenic fractions and incomplete dissolution of the biogenic fraction. We evaluated two alkaline extraction techniques using $0.1 \mathrm{M} \mathrm{Na}_{2} \mathrm{CO}_{3}$ and $0.5 \mathrm{M} \mathrm{NaOH}$ solutions for measuring $\mathrm{Si}_{\mathrm{Alk}}$ as a proxy for environmental change in soil, peat and lake records with volcanic inputs.

Alkaline extraction techniques should be used with caution in tephra-based soil profiles, soils developed on volcanic bedrock or soils with aeolian input containing volcanic material. The influence of the dissolution of glass shards on $\mathrm{BSi}$ measurements in palaeoecological records can be signif- 
icant in oligotrophic environments with a low BSi sediment content. Here, concomitant accumulation of volcanic material will lead to significant contribution of a non-biogenic fraction during the determination of $\mathrm{Si}_{\text {Alk }}$. Otherwise, $\mathrm{Si}_{\text {Alk }}$ determined with traditional alkaline methods can be freely used as a proxy to evaluate environmental changes, especially when part of multi-proxy studies.

Determination of the time course of dissolution during the first $5 \mathrm{~h}$ of extraction using $0.1 \mathrm{M} \mathrm{Na}_{2} \mathrm{CO}_{3}$ has proven to be a sensitive indicator of other forms of $\mathrm{Si}_{\text {Alk }}$. In addition, the sequential $\mathrm{Na}_{2} \mathrm{CO}_{3}$ extraction is a rather simple method and the results show a high recovery of the biogenic Si fraction (Meunier et al., 2014; Saccone et al., 2007). The main advantage of the method is that a relatively large number of samples can be measured in a relatively short time span. In environments with a high $\mathrm{BSi}$ content, the $0.1 \mathrm{M} \mathrm{Na}_{2} \mathrm{CO}_{3}$ method is the preferred one.

We also show that the continuous monitoring of $\mathrm{Si}$ and $\mathrm{Al}$ extraction in $\mathrm{NaOH}$ addresses the main disadvantages of the sequential $\mathrm{Na}_{2} \mathrm{CO}_{3}$ method. Our analysis of pure tephra (i.e. mainly containing glass shards) samples provided important information about the dissolution characteristics of volcanic glass shards. Our study confirms that the dissolution of tephra contributes to $\mathrm{Si}_{\mathrm{Alk}}$ determination, but the distinct signature of glass shard dissolution can help to isolate its contribution to the biogenic fraction. Continuous monitoring of $\mathrm{Si}$ and $\mathrm{Al}$ is promoted to analyse complex samples from any environmental record to reduce uncertainty on biological reactive fractions. Future studies should address the reliability and precision of the separation of different fractions through modelling of dissolution parameters.

Author contributions. W. Clymans, N .Van der Putten and D. J. Conley were responsible for the concept and design of this study. S. Wastegård, S. Björk, N. Van der Putten, B. Moine and G. Gísladóttir advised on and helped with sample collection. W. Clymans, L. Baråo and N. Van der Putten prepared and analysed samples. W. Clymans was responsible for data analysis and interpretation, with inputs on methodology of L. Baråo, E. Struzf and D. J. Conley, as well as interpretation of palaeoecological data by all other authors. W. Clymans provided a first draft. All authors contributed to the writing of the paper.

Acknowledgements. The following people are thanked for their invaluable assistance: S. R. Gíslason for providing fresh tephra (Eyjafjallajökull); A. Cools and D. U. Delmonte for assistance during the continuous extractions; A. Gosh for helping with microscopic analysis; and G. Fontorbe, P. Abbott and S. Davies for advice on sample preparation. Comments by P. Frings, G. Fontorbe, H. Alfredsson, B. Alvarez de Glasby and J. Stadmark help in improving the manuscript. Likewise, the editor, anonymous reviewers and D. J. Lowe are thanked for their constructive comments and suggestions. This research was funded by the Knut \& Alice Wallenberg Foundation, FWO en Belspo (SOGLO). L. Baråo thanks the Special Research Foundation of the University of Antwerp (BOF-UA and NOI) for the PhD fellowship funding.

Edited by: Y. Kuzyakov

\section{References}

Adams, J. K. and Finkelstein, S. A.: Watershed-scale reconstruction of middle and late Holocene paleoenvironmental changes on Melville Peninsula, Nunavut, Canada, Quaternary Sci. Rev., 29, 2302-2314, doi:10.1016/j.quascirev.2010.05.033, 2010.

Ampel, L., Wohlfarth, B., Risberg, J., and Veres, D.: Paleolimnological response to millennial and centennial scale climate variability during MIS 3 and 2 as suggested by the diatom record in Les Echets, France, Quaternary Sci. Rev., 27, 1493-1504, doi:10.1016/j.quascirev.2008.04.014, 2008.

Andresen, C. S., Björck, S., Bennike, O., and Bond, G.: Holocene climate changes in southern Greenland: evidence from lake sediments, J. Quaternary Sci., 19, 783-795, doi:10.1002/jqs.886, 2004.

Barão, L., Clymans, W., Vandevenne, F., Meire, P., Conley, D., and Struyf, E.: Pedogenic and biogenic alkaline - extracted silicon distributions along a temperate land - use gradient, Eur. J. Soil Sci., 65, 693-705, 2014.

Barão, A., Vandevenne, F., Clymans, W., Frings, P., Ragueneau, O., Meire, P., Conley, D. J., and Struyf, E.: Alkaline-extractable silicon from land to ocean: a challenge for biogenic Silicon determination, Limnol. Oceanogr.-Meth., doi:10.1002/lom3.10028, 2015.

Björck, S., Rittenour, T., Rosén, P., França, Z., Möller, P., Snowball, I., Wastegård, S., Bennike, O., and Kromer, B.: A Holocene lacustrine record in the central North Atlantic: proxies for volcanic activity, short-term NAO mode variability, and longterm precipitation changes, Quaternary Sci. Rev., 25, 9-32, doi:10.1016/j.quascirev.2005.08.008, 2006.

Blockley, S. P. E., Pyne-O'Donnell, S. D. F., Lowe, J. J., Matthews, I. P., Stone, A., Pollard, A. M., Turney, C. S. M., and Molyneux, E. G.: A new and less destructive laboratory procedure for the physical separation of distal glass tephra shards from sediments, Quaternary Sci. Rev., 24, 1952-1960, doi:10.1016/j.quascirev.2004.12.008, 2005.

Churchman, J. and Lowe, D. J.: Alteration, formation, and occurrence of minerals in soils, 2nd Edn., Handbook of Soil Sciences, Vol. 1: Properties and Processes, edited by: Huang, P. and Li, Y., CRC Press, Boca Raton, 2012.

Clymans, W., Govers, G., Van Wesemael, B., Meire, P., and Struyf, E.: Amorphous silica analysis in terrestrial runoff samples, Geoderma, 167-168, 228-235, doi:10.1016/j.geoderma.2011.07.033, 2011a.

Clymans, W., Struyf, E., Govers, G., Vandevenne, F., and Conley, D. J.: Anthropogenic impact on amorphous silica pools in temperate soils, Biogeosciences, 8, 2281-2293, doi:10.5194/bg-8-22812011, 2011b.

Clymans, W., Lehtinen, T., Gísladóttir, G., Lair, G., Barão, L., Ragnarsdóttir, K., Struyf, E., and Conley, D.: Si Precipitation During Weathering in Different Icelandic Andosols, Procedia Earth Planet Sci, 10, 260-265, 2014. 
Conley, D. and Schelske, C.: Biogenic Silica, in: Tracking Environmental Change Using Lake Sediments, edited by: Smol, J., Birks, H. J., Last, W., Bradley, R., and Alverson, K., Developments in Paleoenvironmental Research, Springer, the Netherlands, 281293, 2001

Conley, D., Schelske, C., and Stoermer, E.: Modification of the biogeochemical cycle of silica with eutrophication,Mar. Ecol.-Prog. Ser., 101, 179-192, 1993.

Cornelis, J. T., Ranger, J., Iserentant, A., and Delvaux, B.: Tree species impact the terrestrial cycle of silicon through various uptakes, Biogeochemistry, 97, 231-245, doi:10.1007/s10533-0099369-x, 2010.

Cornelis, J.-T., Titeux, H., Ranger, J., and Delvaux, B.: Identification and distribution of the readily soluble silicon pool in a temperate forest soil below three distinct tree species, Plant Soil, 342, 369-378, doi:10.1007/s11104-010-0702-x, 2011a.

Cornelis, J.-T., Delvaux, B., Georg, R. B., Lucas, Y., Ranger, J., and Opfergelt, S.: Tracing the origin of dissolved silicon transferred from various soil-plant systems towards rivers: a review, Biogeosciences, 8, 89-112, doi:10.5194/bg-8-89-2011, 2011 b.

Davies, S. M., Wastegård, S., and Wohlfarth, B.: Extending the limits of the Borrobol Tephra to Scandinavia and detection of new early Holocene tephras, Quaternary Res., 59, 345-352, 2003.

DeMaster, D.: The supply and accumulation of silica in the marineenvironment, Geochim. Cosmochim. Ac., 45, 1715-1732, 1981.

Dixon, J. B. and Weed, S. B.: Minerals in soil environments, 2nd Edn., Minerals in soil environments, Soil Sci. Soc. Am. J., Madison, Wisconsin, USA, 1989.

Dugmore, A. J., Newton, A. J., Sugden, D. E., and Larsen, G.: Geochemical stability of fine-grained silicic Holocene tephra in Iceland and Scotland, J. Quaternary Sci., 7, 173-183, doi:10.1002/jqs.3390070208, 1992.

Fernández, M., Björck, S., Wohlfarth, B., Maidana, N. I., Unkel, I., and Van der Putten, N.: Diatom assemblage changes in lacustrine sediments from Isla de los Estados, southernmost South America, in response to shifts in the southwesterly wind belt during the last deglaciation, J. Paleolimnol., 50, 433-446, doi:10.1007/s10933-013-9736-4, 2013.

Frings, P., Clymans, W., Jeppesen, E., Lauridsen, T., Struyf, E., and Conley, D.: Lack of steady-state in the global biogeochemical Si cycle: emerging evidence from lake $\mathrm{Si}$ sequestration, Biogeochemistry, 117, 255-277, doi:10.1007/s10533-013-9944z, 2014a.

Frings, P. J., Clymans, W., and Conley, D. J.: Amorphous Silica Transport in the Ganges Basin: Implications for Si Delivery to the Oceans, Procedia Earth Planet Sci., 10, 271-274, 2014b.

Gehlen, M. and van Raaphorst, W.: Early diagenesis of silica in sandy North sea sediments: quantification of the solid phase, Mar. Chem., 42, 71-83, doi:10.1016/0304-4203(93)90238-J, 1993.

Gísladóttir, G., Erlendsson, E., Lal, R., and Bigham, J.: Erosional effects on terrestrial resources over the last millennium in Reykjanes, southwest Iceland, Quaternary Res., 73, 20-32, doi:10.1016/j.yqres.2009.09.007, 2010.

Gislason, S. R., Alfredsson, H. A., Eiriksdottir, E. S., Hassenkam, T., and Stipp, S. L. S.: Volcanic ash from the 2010 Eyjafjallajökull eruption, Appl. Geochem., 26, S188-S190, doi:10.1016/j.apgeochem.2011.03.100, 2011a.
Gislason, S. R., Hassenkam, T., Nedel, S., Bovet, N., Eiriksdottir, E. S., Alfredsson, H. A., Hem, C. P., Balogh, Z. I., Dideriksen, K., Oskarsson, N., Sigfusson, B., Larsen, G., and Stipp, S. L.: Characterization of Eyjafjallajökull volcanic ash particles and a protocol for rapid risk assessment, P. Natl. Acad. Sci. USA, 108, 7307-7312, doi:10.1073/pnas.1015053108, 2011 b.

Grasshoff, K., Ehrhardt, M., and Kremling, K.: Methods of Sea Water Analysis, Verlag Chemie, Weinheim, Germany, 1983.

Gudmundsson, A., Oskarsson, N., Grönvold, K., Saemundsson, K., Sigurdsson, O., Stefansson, R., Gislason, S., Einarsson, P., Brandsdottir, B., Larsen, G., Johannesson, H., and Thordarson, T.: The 1991 eruption of Hekla, Iceland, B. Volcanol., 54, 238 246, doi:10.1007/2FBF00278391, 1992.

Guntzer, F., Keller, C., and Meunier, J.-D.: Benefits of plant silicon for crops: a review, Agron. Sustain. Dev., 32, 201-213, 2012.

Gustafsson, J. P., Bhattacharya, P., and Karltun, E.: Mineralogy of poorly crystalline aluminium phases in the B horizon of Podzols in southern Sweden, Appl. Geochem., 14, 707-718, doi:10.1016/S0883-2927(99)00002-5, 1999.

Hafliðason, H., Larsen, G., and Ólafsson, G.: The Recent Sedimentation History of Thingvallavatn, Iceland, Oikos, 64, 80-95, doi:10.2307/3545044, 1992.

Harper, M. A., Howorth, R., and McLeod, M.: Late Holocene diatoms in Lake Poukawa: Effects of airfall tephra and changes in depth, New Zeal. J. Mar. Fresh., 20, 107-118, doi:10.1080/00288330.1986.9516135, 1986.

Hartmann, J. and Moosdorf, N.: The new global lithological map database GLiM: A representation of rock properties at the Earth surface, Geochem. Geophy. Geosy., 13, doi:10.1029/2012GC004370, 2012.

Hashimoto, I. and Jackson, M.: Rapid dissolution of allophane and kaolinite-halloysite after dehydration, Natl. Conf. on Clays and Clay Minerals, Vol. 7, Washington, 102-113, 1960.

Heathcote, A., Ramstack Hobbs, J., Anderson, N. J., Frings, P., Engstrom, D., and Downing, J.: Diatom floristic change and lake paleoproduction as evidence of recent eutrophication in shallow lakes of the midwestern USA, J. Paleolimnol., 53, 17-34, doi:10.1007/s10933-014-9804-4, 2014.

Heyng, A. M., Mayr, C., Lücke, A., Striewski, B., Wastegård, S., and Wissel, H.: Environmental changes in northern New Zealand since the Middle Holocene inferred from stable isotope records $(\delta 15 \mathrm{~N}, \delta 13 \mathrm{C})$ of Lake Pupuke, J. Paleolimnol., 48, 351-366, doi:10.1007/s10933-012-9606-5, 2012.

Hickman, M. and Reasoner, M. A.: Diatom responses to late Quaternary vegetation and climate change, and to deposition of two tephras in an alpine and a sub-alpine lake in Yoho National Park, British Columbia, J. Paleolimnol., 11, 173-188, 1994.

Hodder, A., Green, B., and Lowe, D.: A two-stage model for the formation of clay minerals from tephra-derived volcanic glass, Clay Miner., 25, 313-327, 1990.

Hydes, D. and Liss, P.: Fluorimetric method for the determination of low concentrations of dissolved aluminium in natural waters, Analyst, 101, 922-931, 1976.

ISSS-ISRIC-FAO: World Reference Base for Soil Resources, World Soil Resources Reports, edited by: FAO, Rome, 1998.

Johansson, H., Lind, E. M., and Wastegård, S.: Proximal tephra glass geochemistry from eruptions in the Azores archipelago and possible links with sites in Ireland, The Holocene, submitted, 2015 . 
Johnson, T. C., Brown, E. T., and Shi, J.: Biogenic silica deposition in Lake Malawi, East Africa over the past 150,000 years, Palaeogeogr. Palaeocl., 303, 103-109, doi:10.1016/j.palaeo.2010.01.024, 2011.

Kamatani, A. and Oku, O.: Measuring biogenic silica in marine sediments, Mar. Chem., 68, 219-229, 2000.

Kameník, J., Mizera, J., and Řanda, Z.: Chemical composition of plant silica phytoliths, Environ. Chem. Lett., 11, 189-195, doi:10.1007/s10311-012-0396-9, 2013.

Koning, E., Epping, E., and Van Raaphorst, W.: Determining biogenic silica in marine samples by tracking silicate and aluminium concentrations in alkaline leaching solutions, Aquat. Geochem., 8, 37-67, 2002.

Le Bas, M., Le Maitre, R., Streckeisen, A., and Zanettin, B.: A chemical classification of volcanic rocks based on the total alkalisilica diagram, J. Petrol., 27, 745-750, 1986.

Leinen, M.: Normative calculation technique for determining opal in deep-sea sediments, Geochim. Cosmochim. Ac., 41, 671-676, 1977.

Levard, C., Doelsch, E., Basile-Doelsch, I., Abidin, Z., Miche, H., Masion, A., Rose, J., Borschneck, D., and Bottero, J. Y.: Structure and distribution of allophanes, imogolite and protoimogolite in volcanic soils, Geoderma, 183-184, 100-108, doi:10.1016/j.geoderma.2012.03.015, 2012.

Lind, E. M. and Wastegård, S.: Tephra horizons contemporary with short early Holocene climate fluctuations: new results from the Faroe Islands, Quatern. Int., 246, 157-167, 2011.

Lotter, A., Birks, H., and Zolitschka, B.: Late-glacial pollen and diatom changes in response to two different environmental perturbations: volcanic eruption and Younger Dryas cooling, J. Paleolimnol., 14, 23-47, 1995.

Lowe, D. J.: Stratigraphy, age, composition, and correlation of late Quaternary tephras interbedded with organic sediments in Waikato lakes, North Island, New Zealand, New Zeal. J. Geol. Geop., 31, 125-165, 1988.

Lowe, D. J.: Tephrochronology and its application: A review, Quat. Geochronol., 6, 107-153, doi:10.1016/j.quageo.2010.08.003, 2011.

Lyle, A. O. and Lyle, M.: Determination of biogenic opal in pelagic marine sediments: a simple method revisited, Proceedings of the Ocean Drilling Program, Initial Reports, 1-21, 2002.

Mackie, E. A., Davies, S. M., Turney, C. S., Dobbyn, K., Lowe, J. J., and Hill, P. G.: The use of magnetic separation techniques to detect basaltic microtephra in last glacial-interglacial transition (LGIT; 15-10 ka cal. bp) sediment sequences in Scotland, Scot. J. Geol., 38, 21-30, 2002.

Melzer, S. E., Chadwick, O. A., Hartshorn, A. S., Khomo, L. M., Knapp, A. K., and Kelly, E. F.: Lithologic controls on biogenic silica cycling in South African savanna ecosystems, Biogeochemistry, 108, 317-334, 2012.

Meunier, J. D., Keller, C., Guntzer, F., Riotte, J., Braun, J. J., and Anupama, K.: Assessment of the $1 \% \mathrm{Na} 2 \mathrm{CO} 3$ technique to quantify the phytolith pool, Geoderma, 216, 30-35, doi:10.1016/j.geoderma.2013.10.014, 2014.

Meyer-Jacob, C., Vogel, H., Boxberg, F., Rosén, P., Weber, M. E., and Bindler, R.: Independent measurement of biogenic silica in sediments by FTIR spectroscopy and PLS regression, J. Paleolimnol., 52, 245-255, 2014.
Morley, D. W., Leng, M. J., Mackay, A. W., Sloane, H. J., Rioual, P., and Battarbee, R. W.: Cleaning of lake sediment samples for diatom oxygen isotope analysis, J. Paleolimnol., 31, 391-401, 2004.

Müller, P. and Schneider, R.: An automated leaching method for the determination of opal in sediments and particulate matter, DeepSea Res. Pt. I, 40, 425-444, 1993.

Norddahl, H. and Hafliðason, H.: The Skogar tephra, a Younger Dryas marker in north Iceland, Boreas, 21, 23-41, 1992.

Oelkers, E. H. and Gislason, S. R.: The mechanism, rates and consequences of basaltic glass dissolution: I. An experimental study of the dissolution rates of basaltic glass as a function of aqueous $\mathrm{Al}, \mathrm{Si}$ and oxalic acid concentration at $25 \mathrm{C}$ and $\mathrm{pH}=3$ and 11 , Geochim. Cosmochim. Ac., 65, 3671-3681, 2001.

Ohlendorf, C. and Sturm, M.: A modified method for biogenic silica determination, J. Paleolimnol., 39, 137-142, 2008.

Parfitt, R.: Allophane and imogolite: role in soil biogeochemical processes, Clay Miner., 44, 135-155, 2009.

Pollard, A., Blockley, S., and Ward, K.: Chemical alteration of tephra in the depositional environment: theoretical stability modelling, J. Quaternary Sci., 18, 385-394, 2003.

Prokopenko, A. A., Hinnov, L. A., Williams, D. F., and Kuzmin, M. I.: Orbital forcing of continental climate during the Pleistocene: a complete astronomically tuned climatic record from Lake Baikal, SE Siberia, Quaternary Sci. Rev., 25, 3431-3457, 2006.

Reyerson, P.: Reactive Silica in Loess-Derived Soils of Central North America, Doctor of Philosophy, Geography, University of Wisconsin-Madison, 187 pp., 2012.

Rose, N., Golding, P., and Battarbee, R.: Selective concentration and enumeration of tephra shards from lake sediment cores, The Holocene, 6, 243-246, 1996.

Saccone, L., Conley, D., Koning, E., Sauer, D., Sommer, M., Kaczorek, D., Blecker, S., and Kelly, E.: Assessing the extraction and quantification of amorphous silica in soils of forest and grassland ecosystems, Eur. J. Soil Sci., 58, 1446-1459, 2007.

Sauer, D., Saccone, L., Conley, D., Herrmann, L., and Sommer, M.: Review of methodologies for extracting plant-available and amorphous Si from soils and aquatic sediments, Biogeochemistry, 80, 89-108, 2006.

Sommer, M., Jochheim, H., Höhn, A., Breuer, J., Zagorski, Z., Busse, J., Barkusky, D., Meier, K., Puppe, D., Wanner, M., and Kaczorek, D.: Si cycling in a forest biogeosystem - the importance of transient state biogenic Si pools, Biogeosciences, 10, 4991-5007, doi:10.5194/bg-10-4991-2013, 2013.

Stephens, J. C. and Hering, J. G.: Factors affecting the dissolution kinetics of volcanic ash soils: dependencies on $\mathrm{pH}, \mathrm{CO}_{2}$, and oxalate, Appl. Geochem., 19, 1217-1232, 2004.

Struyf, E. and Conley, D.: Emerging understanding of the ecosystem silica filter, Biogeochemistry, 107, 9-18, 2012.

Telford, R. J., Barker, P., Metcalfe, S., and Newton, A.: Lacustrine responses to tephra deposition: examples from Mexico, Quaternary Sci. Rev., 23, 2337-2353, 2004.

Turney, C. S.: Extraction of rhyolitic component of Vedde microtephra from minerogenic lake sediments, J. Paleolimnol., 19, 199-206, 1998.

Unkel, I., Björck, S., and Wohlfarth, B.: Deglacial environmental changes on Isla de los Estados (54.4 S), southeastern Tierra del Fuego, Quaternary Sci. Rev., 27, 1541-1554, 2008. 
Van Cappellen, P., Dixit, S., and van Beusekom, J.: Biogenic silica dissolution in the oceans: Reconciling experimental and field - based dissolution rates, Global Biogeochem. Cy., 16, 1075, doi:10.1029/2001GB001431, 2002.

Van der Putten, N., Verbruggen, C., Björck, S., Michel, E., Disnar, J.-R., Chapron, E., Moine, B. N., and de Beaulieu, J.-L.: The Last Termination in the South Indian Ocean: a unique terrestrial record from Kerguelen Islands $\left(49^{\circ} \mathrm{S}\right)$ situated within the Southern Hemisphere westerly belt, Quaternary Sci. Revi., 122, 142157, doi:10.1016/j.quascirev.2015.05.010, 2015.

Verschuren, D., Johnson, T., Kling, H., Edgington, D., Leavitt, P., Brown, E., Talbot, M., and Hecky, R.: History and timing of human impact on Lake Victoria, East Africa, Proc. R. Soc. Lon. B, 269, 289-294, 2002.
Wastegård, S., Veres, D., Kliem, P., Hahn, A., Ohlendorf, C., and Zolitschka, B.: Towards a late Quaternary tephrochronological framework for the southernmost part of South America - the Laguna Potrok Aike tephra record, Quaternary Sci. Revi., 71, 8190, 2013.

Wolff-Boenisch, D., Gislason, S. R., Oelkers, E. H., and Putnis, C. $\mathrm{V}$.: The dissolution rates of natural glasses as a function of their composition at $\mathrm{pH} 4$ and 10.6, and temperatures from 25 to $74 \mathrm{C}$, Geochim. Cosmochim. Ac., 68, 4843-4858, 2004.

Wulf, S., Ott, F., Słowiński, M., Noryśkiewicz, A. M., Dräger, N., Martin-Puertas, C., Czymzik, M., Neugebauer, I., Dulski, P., and Bourne, A. J.: Tracing the Laacher See Tephra in the varved sediment record of the Trzechowskie palaeolake in central Northern Poland, Quaternary Sci. Rev., 76, 129-139, 2013. 